PNL-4146

UC-70

\title{
Consolidated Waste Forms: Glass Marbles and Ceramic Pellets
}

R. L. Treat

J. M. Rusin

May 1982

Prepared for the U.S. Department of Energy under Contract DE-AC06-76RLO 1830

Pacific Northwest Laboratory

Operated for the U.S. Department of Energy by Battelle Memorial Institute 


\title{
DISCLAIMER
}

This report was prepared as an account of work sponsored by an agency of the United States Government. Neither the United States Government nor any agency thereof, nor any of their employees, makes any warranty, express or implied, or assumes any legal liability or responsibility for the accuracy, completeness, or usefulness of any information, apparatus, product, or process disclosed, or represents that its use would not infringe privately owned rights. Reference herein to any specific commercial product, process, or service by trade name, trademark, manufacturer, or otherwise, does not necessarily constitute or imply its endorsement, recommendation, or favoring by the United States Government or any agency thereof. The views and opinions of authors expressed herein do not necessarily state or reflect those of the United States Government or any agency thereof.

\author{
PACIFIC NORTHWEST I.ABORATORY \\ operated by \\ BATTELLE \\ for the \\ UNITED STATES DEPARTMENT OF ENERGY \\ under Contract DE-AC06-76RLO 1830
}

\begin{tabular}{|c|c|}
\hline \multicolumn{2}{|c|}{$\begin{array}{c}\text { National Technical Information Service } \\
\text { United States Department of Commerce } \\
5285 \text { Port Royal Road } \\
\text { Springfield, Virginia } 22151\end{array}$} \\
\hline \multicolumn{2}{|c|}{$\begin{array}{l}\text { NTIS Price Codes } \\
\text { Microfiche A01 }\end{array}$} \\
\hline \multicolumn{2}{|c|}{ Printed Copy } \\
\hline Pages & $\begin{array}{l}\text { Price } \\
\text { Codes }\end{array}$ \\
\hline $001-025$ & $\mathrm{~A} 02$ \\
\hline $026-050$ & $\mathrm{~A} 03$ \\
\hline $051-075$ & $A 04$ \\
\hline $076-100$ & A05 \\
\hline $167-125$ & A06 \\
\hline $126-150$ & $\mathrm{~A} 07$ \\
\hline $151-175$ & $\mathrm{~A} 08$ \\
\hline $176-200$ & A09 \\
\hline $201-225$ & A010 \\
\hline 226.250 & A011 \\
\hline $251-275$ & A012 \\
\hline $276-300$ & $\mathrm{~A} 013$ \\
\hline
\end{tabular}


PNL-4146

UC-70

CONSOL IDATED WASTE FORMS:

GLASS MARBLES AND CERAMIC PELLETS
R. L. Treat
J. M. Rusin

May 1982

Prepared for the U.S. Department of Energy under Contract DE-AC06-76RLO 1830

Pacific Northwest Laboratory

Richland, Washington 99352 
Glass marbles and ceramic pellets have been developed at Pacific Northwest Laboratory as part of the multibarrier concept for immobilizing high-level radioactive waste. These consolidated waste forms served as substrates for the application of various inert coatings and as ideal-sized particles for encapsulation in protective matrices. Marble and pellet formulations were based on existing defense wastes at Savannah River Plant and proposed commercial wastes.

To produce marbles, glass is poured from a melter in a continuous stream into a marble-making device. Marbles were produced at PNL on a vibratory marble machine at rates as high as $60 \mathrm{~kg} / \mathrm{h}$. Other marble-making concepts were also investigated. The marble process, including a lead-encapsulation step, was judged as one of the more feasible processes for immobilizing high-level wastes.

To produce ceramic pellets, a series of processing steps are required, which include:

- spray calcining--to dry liquid wastes to a powder;

- disc pelletizing--to convert waste powders to spherical pellets;

- sintering--to densify pellets and cause desired crystal formation. These processing steps are quite complex, and thereby render the ceramic pellet process as one of the least feasible processes for immobilizing highlevel wastes. 
SUMMARY $\quad \cdot \quad \cdot \ldots, \ldots i j$

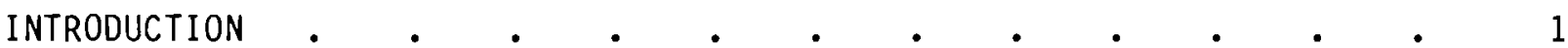

GLASS MARBLE PRODUCTION

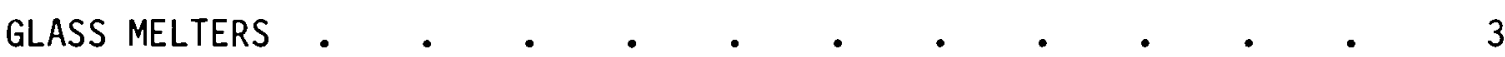

GLASS PROPERTIES $\quad$ • $\quad$ • $\quad$ • $\quad$ •

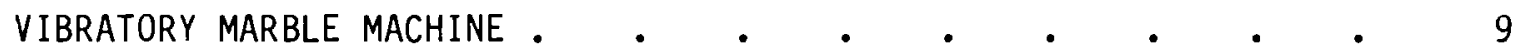

ALTERNATIVE METHODS OF PRODUCING MARBLES. $\quad$ • $\quad$ • $\quad$ • $\quad$ • $\quad$ • 14

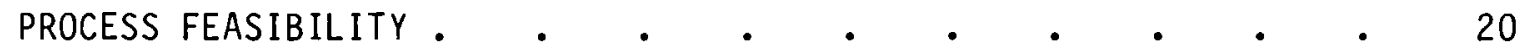

CERAMIC PELLET PRODUCTION

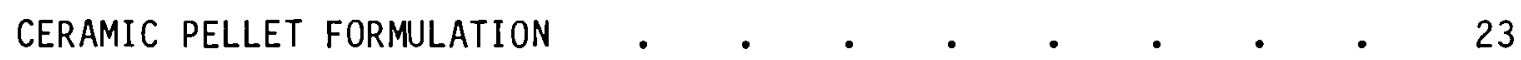

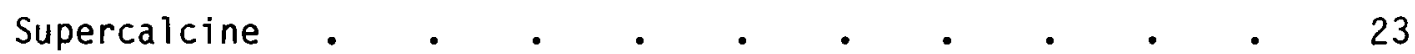

Savannah River Plant Waste Ceramic . . . . . 30

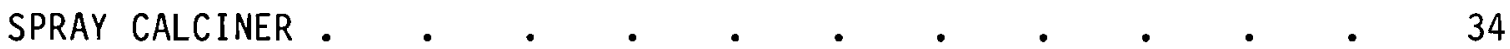

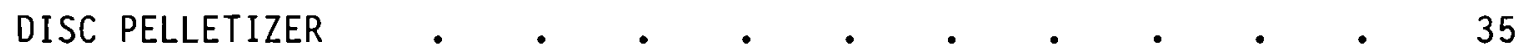

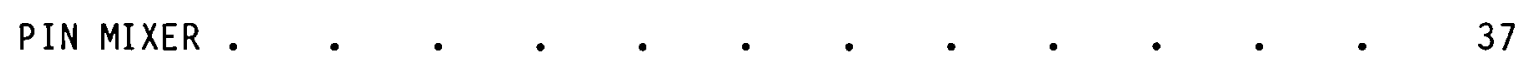

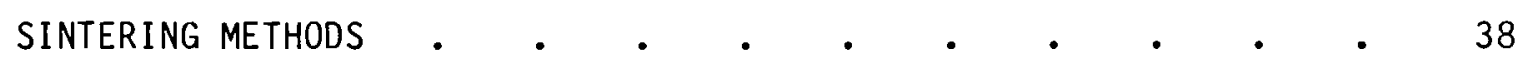

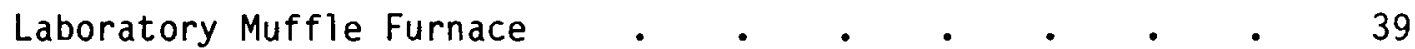

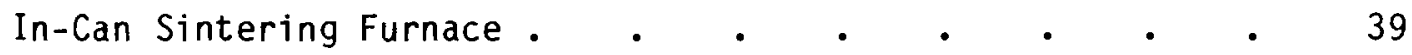

Vertical Sintering Kiln . . . . . . . . . . 40

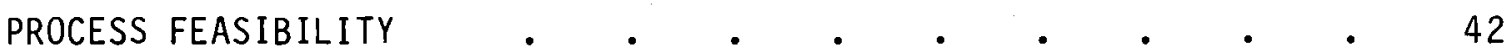

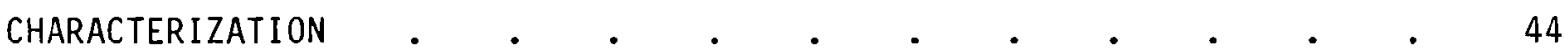

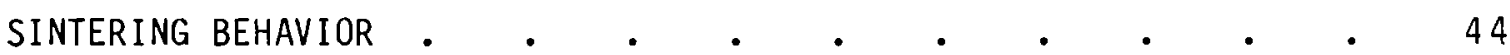

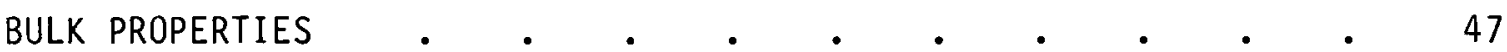

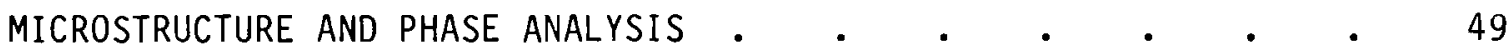




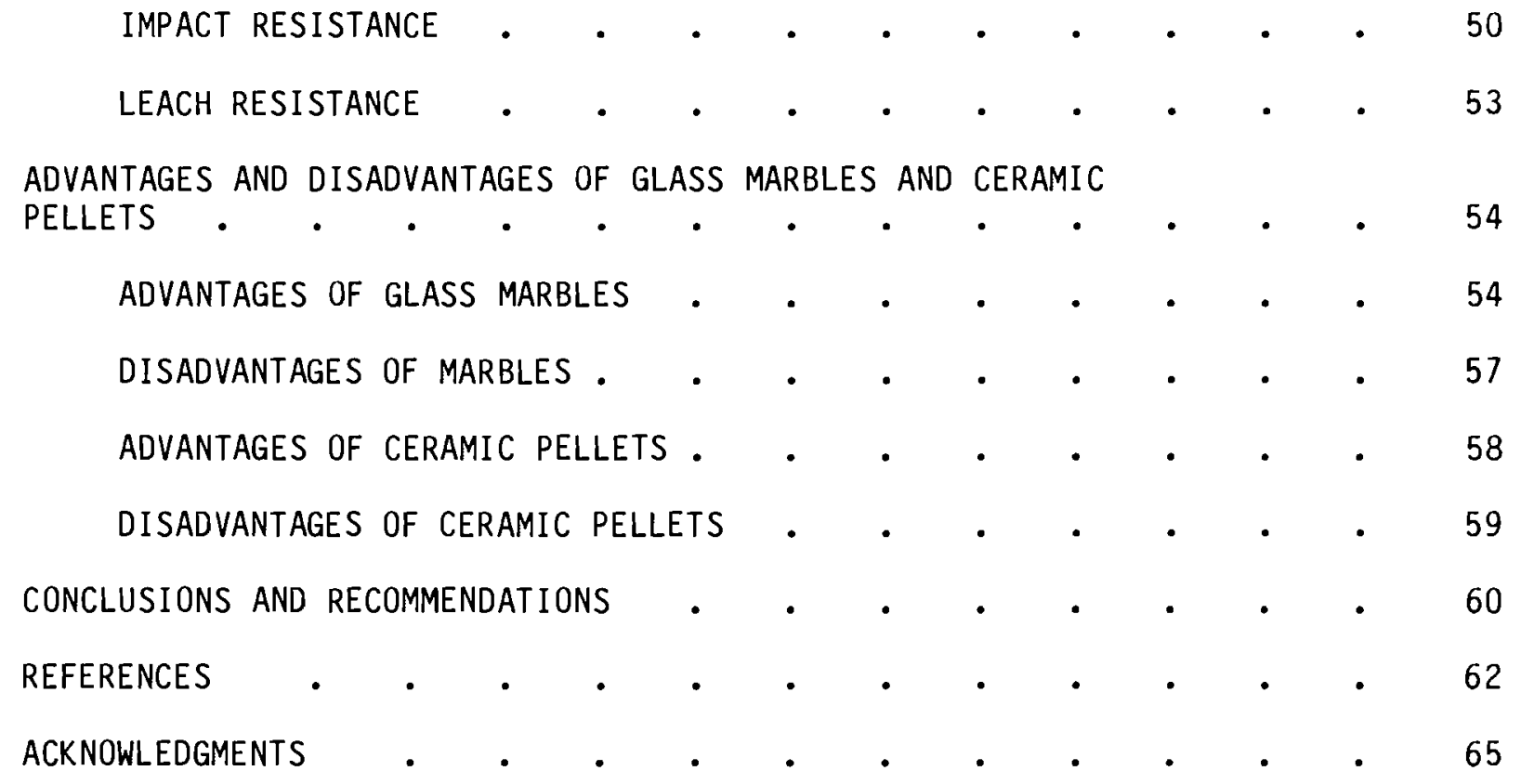

v 
FIGURES

1 Schematic of Liquid-fed Ceramic Melter . . . . . . . 4

2 Viscosity of Soda-Lime and ICM-11 Waste Glass . . . . 8

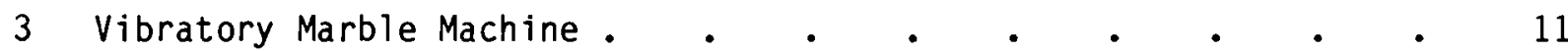

4 Mold Design for PNL Vibratory Marble Machine . . . . . $\quad 11$

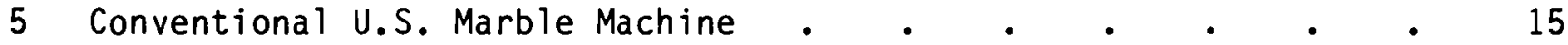

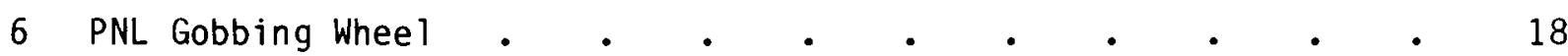

7 Bead-Making Device at Rocky Flats Plant . . . . . . . $\quad$. 18

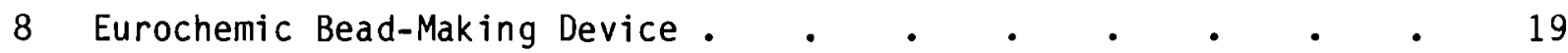

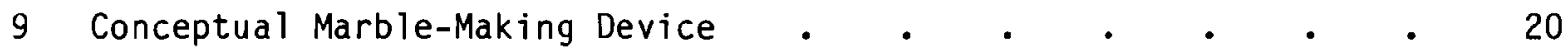

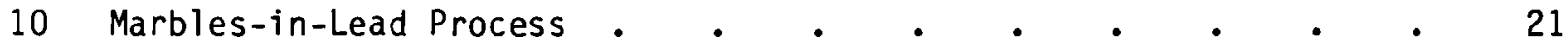

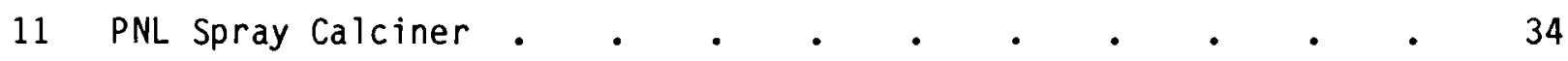

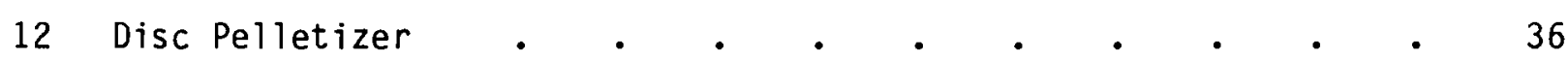

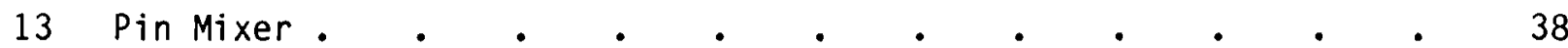

14 Vertical Sintering Kiln . . . . . . . . . . . 41

15 Supercalcine Pellets in Lead Matrix Process . . . . . . 43

16 Bulk Density of Supercalcine SPC-5P After Sintering Various

17 Bulk Density of Supercalcine SPC-5P After Sintering for
2 hours at Various Temperatures $\quad . \quad$. $\quad . \quad$. . . 46

18 Relative Crystalline Phase Content for Supercalcine (SPC-5P) Sintered at $1100^{\circ} \mathrm{C}$ for Various Time Periods . . . . . . 48

19 Relative Crystalline Phase Content for Supercalcine (SPC-5P) Versus Sintering Temperature . $. \quad . \quad . \quad . \quad . \quad . \quad . \quad 49$

20 Micrographs of Simulated Waste Glass Marbles and DisC 


\section{TABLES}

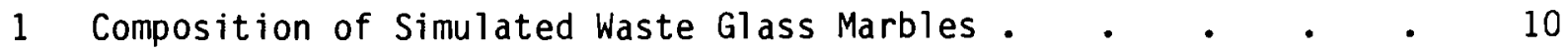

2 Composition of High-Level Liquid Waste Streams . $\quad$ • $\quad$ • 24

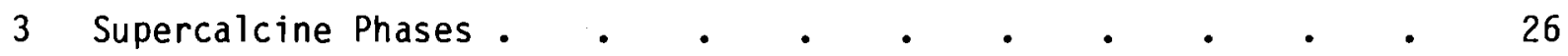

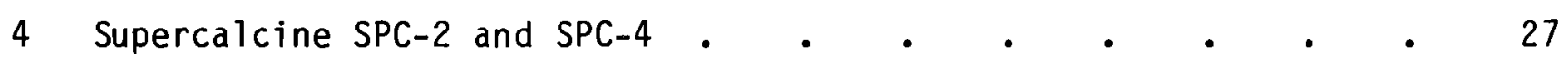

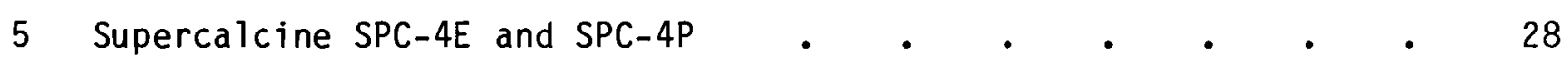

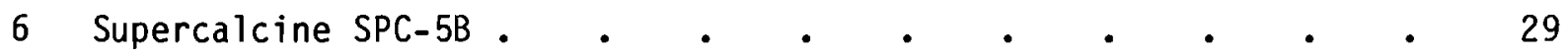

7 Composition of Simulated SRP Calcine Powder . . . . . . . 31

8 Composition of SRP Ceramic Formulations and Glass Powders . $\quad 32$

9 SRP Ceramic Pellet Compositions After Firing • • • • • • 33

10 Bulk Properties of Simulated Waste Glass Marbles and Ceramic
Pellet Waste Forms..

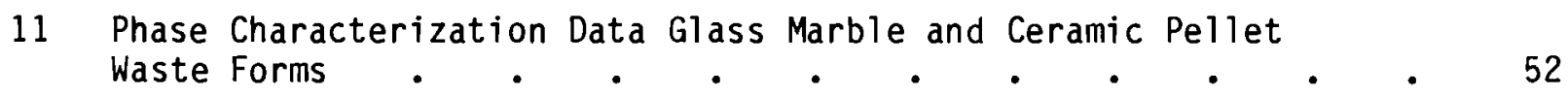

12 Leaching Results for Consolidated Waste Forms . . . . 53 


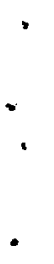




\section{INTRODUCTION}

For the past decade, Pacific Northwest Laboratory ( $P N L$ ) has been developing and evaluating alternative waste forms for the immobilization of high-level nuclear wastes. The Alternative Waste Forms Program was established at PNL in 1979 for the U.S. Department of Energy to evaluate coated particles, particles encapsulated in matrices, and glass-ceramics as candidate waste forms. This report documents the studies that were conducted within this program in the development of consolidated particles. Similarly, efforts in coated particle, glass-ceramic, and matrix development have been documented elsewhere (Oma 1981; Rusin 1981; Wald 1981).

Consolidated particles or waste forms are part of the multibarrier concept (Rusin, Browning and McCarthy 1979). The multibarrier cancept aims to separate the radionuclide-containing consolidated particles from the environment by the use of coatings and/or matrices. The coating barrier can provide improved leach and oxidation resistance and mechanical strength. The matrix may either be used for direct containment of the consolidated particle or as a barrier to the environment. The multibarrier concept has been demonstrated on scales that yielded products ranging from 1 L (Rusin 1978) to $25 \mathrm{~L}$ (Nelson, et al. 1981).

The consolidated waste form is designed to offer some improvement in durability over the original unconsolidated material (e.g., calcine). Additions are made to the unconsolidated waste material to produce waste forms such as glass, glass ceramics, sintered ceramics, and crystalline ceramics that offer improved leach resistance and thermal stability. Since the consolidated waste form may be coated or encapsulated as part of the miultibarrier concept, its compatibility with subsequent processing steps is of utmost importance. For example, volatility must be kept at a minimum during the coating process, otherwise radionuclides can be trapped in the coating, thereby compromising the quality of the coating. Reactions between consolidated forms and coatings and/or encapsulation materials must also be 
controlled. One obvious and most essential requirement is that the maximumuse temperature of the consolidated form be bel ow the processing temperature required for coating or encapsulation.

This report discusses the production and characterization of two types of consolidated waste forms: glass marbles and ceramic pellets. Marbles and pellets have subsequently been used in the coated particle and matrix development studies at PNL. Two basic glass formulations were used: one based upon proposed commercial power wastes, the other based upon existing defense wastes at Savannah River Plant (SRP). Marbles were produced on a vibratory marble machine at rates as high as $60 \mathrm{~kg} / \mathrm{h}$. Other concepts for manufacturing marbles are also presented.

Ceramic pellets were produced by a commercially available disc pelletizer. The pellets were consolidated and crystallized to the final ceramic waste form by heat treating in either a lab furnace, an in-can sintering furnace, or a vertical sintering kiln. Two ceramic formulations were used. One, silicate-based and called "supercalcine," was developed for proposed commercial power wastes. The other ceramic formulation was developed for existing SRP defense wastes.

Both the glass and ceramic consolidated waste forms were characterized for bulk properties, microstructure and phase analyses, and product durability. Dense (i.e., low-porosity) ceramic forms are desired; thus, the sintering behavior of the consolidated ceramic products was also examined. Product durability included impact resistance, thermal stability and leach resistance.

In the final section of the report, advantages and disadvantages are discussed for both glass marble and ceramic pellet waste forms. Areas of further research are then presented along with conclusions based upon the study results. 
GLASS MARBLE PRODUCTION

The PNL glass marble production process has been judged to be one of the more feasible alternatives for immobilizing high-level wastes (HLW). The process consists of 1) a joule-heated glass melter capable of delivering a continuous stream of glass, and 2) a vibratory marble machine. Joule-heated glass melters have been under development at PNL since 1973. Glass composition and properties are very important because a very fluid glass having a sufficient "working range" must be delivered to the marble machine. The machine is based on a patented process developed by Corning Glass Works and differs considerably from conventional marble machines. The Corning machine employs vibrated molds which convert hot gobs of glass into spherical marbles.

\section{GLASS MELTERS}

The feasibility of producing glass from simulated nuclear wastes and glass formers was demonstrated more than 20 years ago (White and LaHaie 1955; Watson et al. 1958; Goldman et al. 1958). Engineering-scale demonstrations using actual HLW have been conducted in the United States (McElroy et al. 1972; Hanson and Bjorklund 1980). High-level waste has been converted to glass in a production process in France (Sombret 1978). However, the melters used in these processes may not be suitable for producing marbles since they produce glass on a batch basis.

In contrast, a glass melter that produces a continuous stream of glass has been under development at PNL since 1975 (Brouns et al. 1980). Similar melters are under development at Savannah River Plant (SRP) (Ferguson et al. 1981), at Rocky Flats Plant (Ledford 1979), and in Germany (Vangeel 1980). Each of these melters utilizes joule-heating to produce a glass melt from nuclear wastes and glass formers. Joule-heating occurs when electrical current is passed through molten glass in the melter. The resulting heat is sufficient to melt the wastes and glass formers at high rates. Glass production rates of over $100 \mathrm{~kg} / \mathrm{h}$ have been demonstrated at PNL with the use of simulated high-level power-reactor wastes and SRP wastes (Dierks 1980). 
A joule-heated glass melter consists of a ceramic-lined cavity containing one or more pairs of electrodes that are positioned against opposite walls of the cavity (Figure 1). Electrodes are constructed of electrically conductive refractory materials. Incone $1690^{\circledR}$ is a candidate electrode material highly

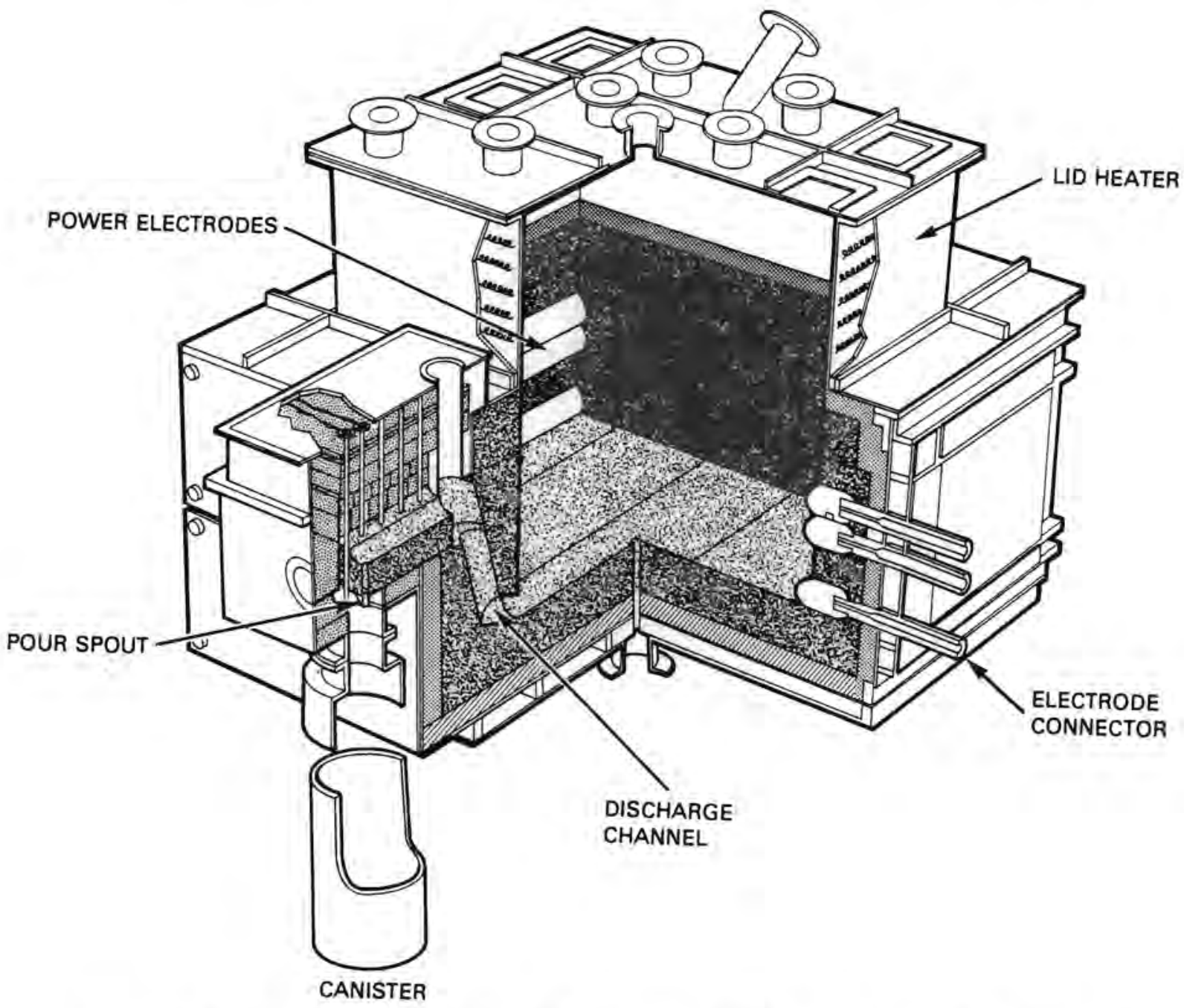

FIGURE 1. Schematic of Liquid-Fed Ceramic Melter. Note electrodes.

(A) Incone1-690, Huntington Alloys Division of the International Nickel Company, Inc., Huntington, West Virginia. 
resistant to oxidizing and reducing conditions as well as to the corrosive salts that are present in many nuclear wastes. Molybdenum is a suitable electrode material only if reducing conditions are maintained. Tin oxide is an acceptable electrode material for oxidizing glasses melted at temperatures above the service limit of Inconel $690^{\circledR}$ (about $1100^{\circ} \mathrm{C}$ ).

The ceramic material that lines the melter cavity consists of highly refractory bricks, such as those made of Monofrax K-3. ${ }^{\circledR}$ The bricks are housed in a metal shell to ensure containment of radioactive dusts and gases. In some melter designs, a weir exists at the base of one of the walls in the melter cavity. Molten glass flows under the weir and rises through a heated overflow section. Eventually the glass spills from a discharge point in a continuous stream. Heating of the glass in the overflow section and after its discharge is required to ensure that the glass has suitable flow characteristics for the casting of the glass into marbles. Overheating the glass must be avoided to minimize vaporizing semivolatile, radioactive species, such as cesium.

Starting and stopping the flow of glass from this type of melter can be accomplished with the use of at least three different techniques. One requires tilting the melter forward several degrees as if pouring water from a teapot (Barnes and Larson 1981). Tilting the melter back stops the flow of glass. Another method, "airlifting," requires that air be bubbled into the glass through a hole adjacent to the weir in the overflow section (Barnes 1980). This method relies upon the density difference between the lighter, aerated glass in the overflow section and the denser glass in the melter cavity. The lighter glass rises as it attempts to counter-balance the pressure head of the heavier glass. Pouring rates can be adjusted by increasing or decreasing the flow of air. A third technique under development at Savannah River Laboratory requires the application of a vacuum to the overflow section. In this approach, glass flows from the melter as it attempts to equalize the pressure on each side of the weir.

(®) Monofrax $\mathrm{K}-3$ is a registered trademark of Carborundum Company. 
In another design which does not employ an overflow section, glass is poured through a metal freeze valve positioned in the bottom of the melter (Chapman 1976). The orifice size of the freeze valve, and changing the temperature of the valve, control the glass pouring rates. Heating is provided by electric inductive-coupling or by electric resistance heaters which surround the freeze valve. Air or steam passed across the surfaces of the valve provides cooling. Glass pouring is started and stopped by the application of high heating and cooling rates, respectively. Regardless of the method selected for pouring glass from a melter, starting and stopping the flow of glass should be accomplished quickly and cleanly to minimize the quantity of scrap marbles generated.

In making glass in a joule-heated melter, nuclear wastes and glass formers are usually added as a dry blend or as a blended aqueous slurry. When an aqueous slurry is used, melting rates are about $1 / 3$ of those possible with a dry blend. Ideally, the blend should be well-mixed and should consist of finely divided solids to ensure rapid and homogeneous melting.

Refractory waste materials that are not well mixed with glass formers may form refractory crusts on the surface of the molten glass that resist melting. This material may settle to the bottom of the melter as unmelted "stones." Stones may also be produced if the temperature of the glass is allowed to drop below the solubility point for certain materials. In this case, materials such as spinels will crystallize from the molten glass and settle to the bottom of the melter. Even at high operating temperatures and with good blending of waste and glass formers, some materials (such as palladium and rhodium) resist dissolving in the glass and also settle in the melter. These undissolved materials may be swept into the overflow section and subsequently be discharged with the glass. Since the thermal expansion coefficients of the undissolved materials and glass may vary significantly, marbles may fracture due to uneven stresses imparted during their cooldown. Aside from causing fractures and somewhat increasing glass surface area, there is no evidence that undissolved materials in the glass degrade the suitability of glass for immobilizing nuclear wastes. 
Some salts, such as alkali sulfates and molybdates, also resist decomposition and dissolution in the glass. These salts are less dense than molten glass and, hence, float on the surface of the glass. If not controlled, salts may accumulate in the melter to the point that they are swept out of the melter with the glass. The presence of salts may also affect the suitability of the glass for marbles manufacture since water-soluble salts would exist as droplets inside and on the surfaces of marbles. As such, salts may weaken the marbles and/or produce a highly leachable coating on the surfaces of the marbles. Such a coating could be easily be removed by washing, however.

\section{GLASS PROPERTIES}

Several properties characterize glasses that are suitable for the production of marbles. One property is the ability of the marble to resist breakage caused by stresses generated as the marble is being formed and subsequently cooled. Because the surface of the marble cools below the softening point of the glass before the interior does, and because glass contracts upon cooling, the surface attempts to compress the glass in the interior. This compression places the surface under tension. As the interior cools and contracts, the surface tensile stresses are relieved. Further cooling of the interior glass then places the surface under compression. Physical properties of a glass that minimize marble surface stresses are: a low Young's modulus, a low coefficient of thermal expansion, a high thermal conductivity, a low density, and a low heat capacity.

Another desirable glass property is a wide "working range." The working range is the temperature interval between the flow point $\left(\sim 10^{5}\right.$ poise) and the softening point $\left(\sim 10^{7.5}\right.$ to $10^{8.0}$ poise) of the glass (Shund 1958). A wide working range permits sufficient forming time for a gob of glass to be molded into a sphere and for more even surface cooling. The working range of a typical soda-lime glass used for making marbles is shown in Figure 2. Sodalime glass has a much longer working range than simulated waste glass as 


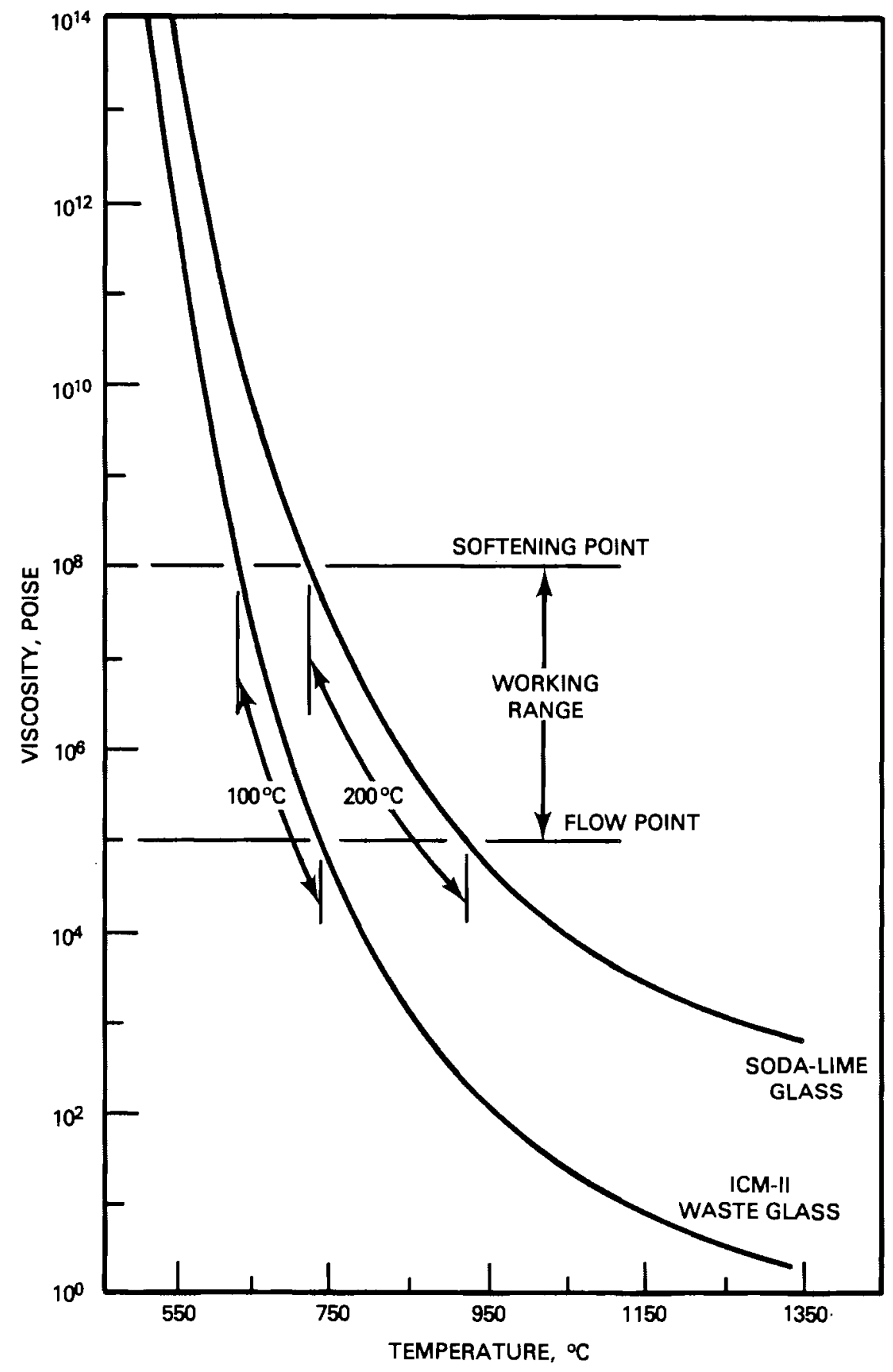

FIGURE 2. Viscosity of Soda-Lime and ICM-11 Waste Glass 
illustrated. This waste glass is not well suited for the conventional United States marble technique described later.

Glass, as it is poured into the marble-making device, must also have a suitable viscosity and surface tension to enable the glass stream to be separated into gobs for marble production. The desired viscosity and surface tension are ensured by controlling the glass composition and temperature. The required temperature depends upon the size and production rate of the marbles, and the process used. The glass-pouring temperature must not be excessive to avoid vaporizing volatile species such as cesium.

Glasses that are homogeneous are best suited for producing marbles. Glasses containing defects, such as undissolved "stones," bubbles, and separated phases, may be subjected to additional stresses at the glass/defect interface. Large, angular "stones" that have coefficients of thermal expansion that are significantly lower than that of the glass may cause high tensile stresses in the marble and a high rate of marble breakage. Compositions of two waste glasses from which marbles were successfully made are given in Table 1.

More than $1500 \mathrm{~kg}$ of marbles having approximately the SRP waste composition shown were made at PNL in a production-scale marble machine. Three kilograms of marbles were also produced from the power-reactor waste glass (ICM-11) with a vibratory, hand-casting technique (Rusin et al. 1978). Although these marbles were annealed at $500^{\circ} \mathrm{C}$ for 2 hours to relieve stresses, some marbles cracked. The presence of "stones" and bubbles was suspected as the cause of the cracking.

\section{VIBRATORY MARBLE MACHINE}

A marble-making device was built and operated at PNL with the use of a concept patented by Corning Glass Works (U.S. Patent 3254979). The marble machine consists of molds which are vibrated and mounted on a continuous, driven chain (Figure 3 ). The hemispherically shaped molds (Figure 4) pass under a falling stream of molten glass. The hot glass collects as a gob in each mold. Vibrating the molds aids in severing the stream of glass between 
TABLE 1. Composition of Simulated Waste Glass Marbles

\begin{tabular}{|c|c|c|c|}
\hline \multicolumn{2}{|c|}{ SRP Waste Glass (a) } & \multicolumn{2}{|c|}{ ICM-11 Waste Glass (b) } \\
\hline Component & $w t \%$ & Component & $w t \%$ \\
\hline $\mathrm{Al}_{2} \mathrm{O}_{3}$ & 7.52 & $\mathrm{~B}_{2} \mathrm{O}_{3}$ & 10.07 \\
\hline $\mathrm{B}_{2} \mathrm{O}_{3}$ & 9.22 & $\mathrm{BaO}$ & 2.24 \\
\hline $\mathrm{BaO}$ & 0.83 & $\mathrm{CaO}$ & 1.33 \\
\hline $\mathrm{CaO}$ & 4.01 & $\mathrm{CdO}$ & 0.06 \\
\hline $\mathrm{Ce}_{2} \mathrm{O}_{3}$ & 0.83 & $\mathrm{CO}_{3} \mathrm{O}_{4}$ & 0.18 \\
\hline $\mathrm{Co}_{2} \mathrm{O}_{3}$ & 0.08 & $\mathrm{Cr}_{2} \mathrm{O}_{3}$ & 0.20 \\
\hline $\mathrm{Cr}_{2} \mathrm{O}_{3}$ & 0.12 & $\mathrm{Fe}_{2} \mathrm{O}_{3}$ & 2.80 \\
\hline CuO & 0.03 & $\mathrm{~K}_{2} \mathrm{O}$ & 4.33 \\
\hline $\mathrm{Dy}_{2} \mathrm{O}_{3}$ & 0.16 & $\mathrm{MgO}$ & 1.33 \\
\hline $\mathrm{Fe}_{2} \mathrm{O}_{3}$ & 5.48 & $\mathrm{MoO}_{3}$ & 3.70 \\
\hline $\mathrm{Gd}_{2} \mathrm{O}_{3}$ & 0.08 & $\mathrm{Na}_{2} \mathrm{O}$ & 3.73 \\
\hline $\mathrm{La}_{2} \mathrm{O}_{3}$ & 0.52 & $\mathrm{NiO}$ & 0.61 \\
\hline $\mathrm{Li}_{2} \mathrm{O}$ & 5.76 & $\mathrm{P}_{2} \mathrm{O}_{5}$ & 1.56 \\
\hline $\mathrm{MgO}$ & 0.66 & $\mathrm{SiO}_{2}$ & 24.67 \\
\hline $\mathrm{MnO}_{2}$ & 1.85 & SrO & 1.95 \\
\hline $\mathrm{MoO}_{3}$ & 1.19 & $\mathrm{TeO}_{2}$ & 0.42 \\
\hline $\mathrm{Na}_{2} \mathrm{O}$ & 9.21 & $2 n 0$ & 19.27 \\
\hline $\mathrm{Nd}_{2} \mathrm{O}_{3}$ & 0.47 & $\mathrm{ZrO}_{2}$ & 2.88 \\
\hline $\mathrm{NiO}$ & 0.57 & Rare Earth Oxides & 18.62 \\
\hline $\mathrm{SiO}_{2}$ & 39.2 & & \\
\hline sro & 0.73 & & \\
\hline $\mathrm{TiO}_{2}$ & 0.19 & & \\
\hline $\mathrm{Zn} 0$ & 7.08 & & \\
\hline
\end{tabular}

(a) Simulated SRP waste glass.

(b) Glass obtained from In-Can Melt (ICM-11) (McElroy 1975)

gobs, and subsequently causes the gobs to rotate and spin in the molds until spheres are formed. By the time the spheres have reached the end of the marble-making device, they are sufficiently hardened that they can be dumped 


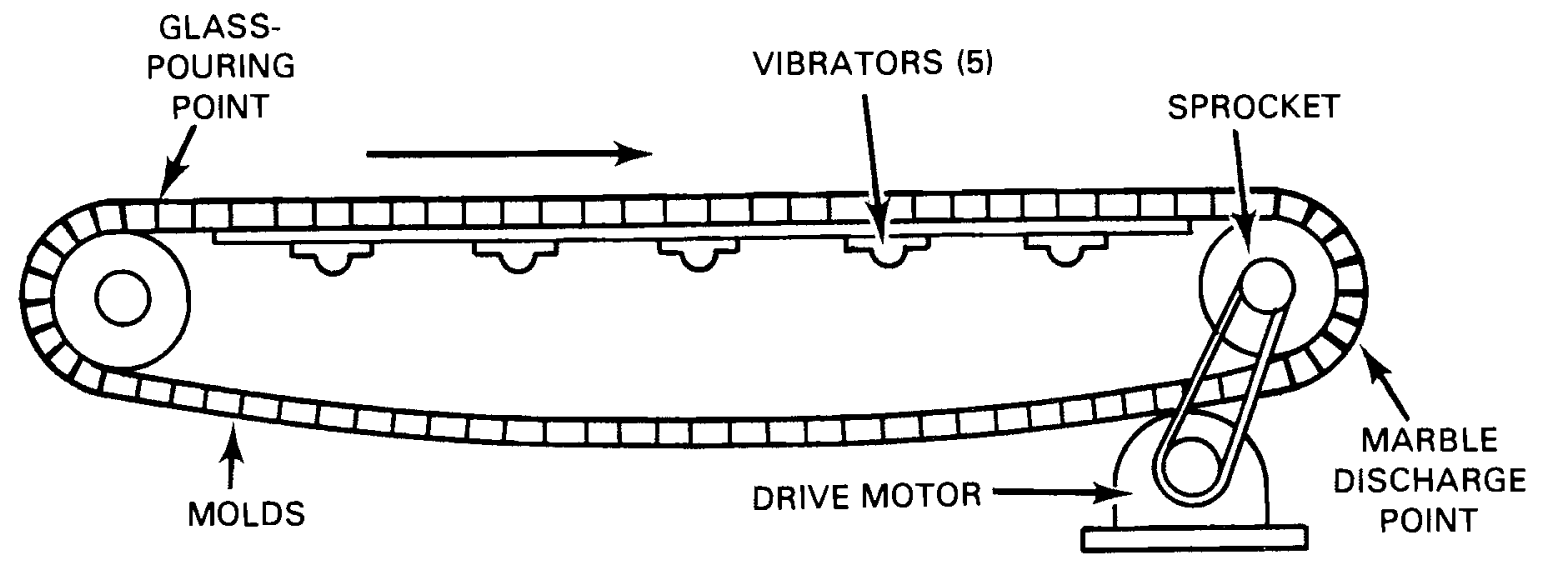

MACHINE LENGTH $\sim 5 \mathrm{~m}$

FIGURE 3. Vibratory Marble Machine

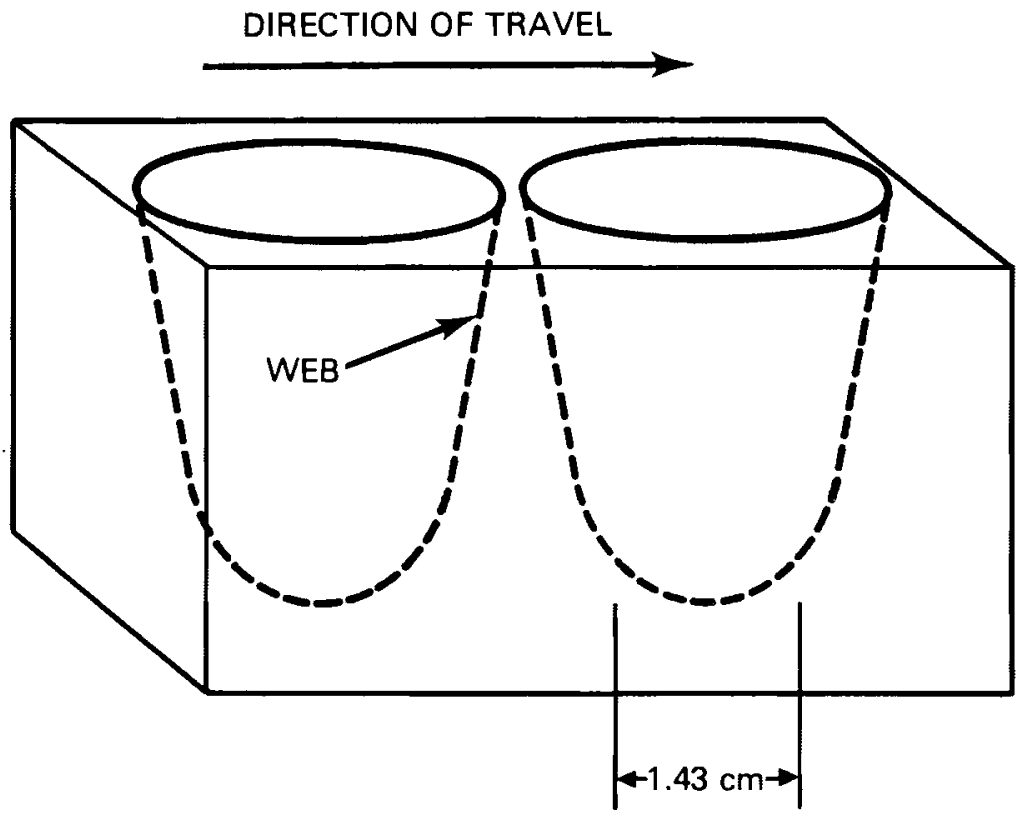

FIGURE 4. Mold Design for PNL Vibratory Marble Machine

from the molds without deforming. Further cooling may be required to prevent marbles in contact from sticking to one another.

During marble production with SRP glass compositions similar to that shown in Table 1 , production rates of $60 \mathrm{~kg} / \mathrm{h}$ have been demonstrated. Cooling 
the molds with a water spray or compressed air was required to sustain this rate. Without water or air cooling, rates of $25 \mathrm{~kg} / \mathrm{h}$ are typical. Higher rates without cooling are potentially achievable by lengthening the device. This would serve to provide the same residence time. Higher rates can also be achieved by simultaneously casting two or more streams of glass into molds mounted side-by-side. Corning Glass Works has demonstrated the feasibility of this approach.

Molds in the PNL marble machine are designed to produce marbles having a maximum diameter of about $1.25 \mathrm{~cm}$. The marble size is determined by the volume of molten glass which collects in each mold. If too much glass collects in a mold, gumdrop-shaped beads result. High-quality marbles as small as $0.5 \mathrm{~cm} /$ dia have been produced. Small marbles can be produced at high numerical rates, but at approximately the same mass rate as that of larger marbles. This is because larger diameter marbles require a longer residence time in the molds to cool and harden due to their lower surface-to-volume ratios.

To produce high-quality marbles, the molds must be hotter than $\sim 100^{\circ} \mathrm{C}$ to avoid thermal shock to the marbles as they are cooled. Marbles that are cooled too quickly may break in the molds or during subsequent handling. Molds on the PNL machine are initially heated by glass poured into the molds. This heating sometimes results in about 5 minutes' production of scrap marbles that must be recycled. To minimize the production of scrap, molds could be heated by other methods before glass is poured.

Another requirement for producing high-quality marbles is adequate vibration. Vibration of the PNL marble machine is provided by five air operated ball vibrators. Depending on the air pressure setting, these vibrators operate at a rated frequency of between 9,000 and 11,000 VPM and deliver between 500 and $8001 b_{f}$ each. Amplitude of vibration is $\sim 0.15 \mathrm{~cm}$.

Immediately after glass is poured into a mold, a high-frequency, lowamplitude vibration is desired. This type of vibration increases the rate at which the hot glass "strings" that connect newly formed glass gobs are broken and flow down into the molds. If the glass strings are not broken within a few seconds after pouring, the strings may harden. This results in V-shaped 
glass pieces and marbles with "tails" that resemble polliwogs. After the strings have been broken and the glass has cooled to its working range, a high-amplitude, multidirectional vibration is desired. This vibration causes the glass gobs to spin and roll in random rotations. This permits even exposure of the surface of the gob to the surface of the mold, which results in even malleation and transfer of heat away from the gob. If exposure to the mold is not even, nonspherical shapes may be formed or uneven marble surface stresses may result, which cause marbles to fracture. Multidirectional vibration is best provided by mounting individual vibrators in different planes. In tests conducted at PNL, orienting the vibrators in the same plane and in parallel planes resulted in producing an observably higher proportion of nonperfect marbles.

Another requirement for making high-quality marbles is a steep-sided, finely polished, and sharpened "web" between individual mold cups (Figure 4). These features induce the fast breaking of the glass strings between molds and the subsequent flow of the broken strings into the molds. This minimizes the production of marbles with tails, the most common form of unacceptable marbles. The application of graphite powder onto the web surfaces was also found to reduce the incidence of marbles with tails. Presumably, the graphite provided lubrication that enabled the strings of glass to flow faster into the molds. The application of ceramic powders to the webs had the opposite effect in that a much higher rate of tail formation was observed. It had been speculated that ceramic powders might provide an insulative coating that would retard heat transfer from the glass string to the mold webs, thereby enabling the strings to retain their ability to flow for a longer period of time. Although some benefit may have resulted, it apparently was more than overcome by the roughness of the coating and the tendency of the glass to wet the powders. These effects retarded the flow of the strings into the mold cups.

An integral part of the marble-making process is a sorter for separating spherical marbles from glass waste forms having other shapes. The device tested at PNL consists of a flat plate slightly tilted in two planes from horizontal. A vibrator is mounted on the underside of the plate. Marbles and 
scrap pour from the marble machine onto the high end of the plate. Only spherical marbles roll freely to the low end of the plate. The nonspherical glass waste forms veer off the side of the plate with the aid of vibration which induces sliding of flat-sided waste forms. Scrap glass can be directly recycled to the glass melter with the use of auger-fed or vibration-fed tote bins that are moved by an overhead crane. Scrap glass can also be ground and pneumatically transferred to a glass recycle bin above the melter.

\section{ALTERNATIVE METHODS OF PRODUCING MARBLES}

The production of marbles in the United States commonly employs: 1) a device that shears a continuously poured stream of glass into two streams of gobs, and 2) a pair of marble formers, each consisting of a set of counterrotating, threaded cylinders which serve to cool the gobs and mold them into spheres (Figure 5). The threaded cylinders on which marbles are formed are aligned with only a small gap between the peaks of the individual roll threads. While glass gobs travel the length of the cylinders, they are rotated and formed into marbles within the the thread grooves. When newly formed marbles reach the end of the cylinders, they are still somewhat viscous. Hence, they must be allowed to cool further on chutes or on trays before they can be stored.

Although this method of making marbles does not require an unusually high level of maintenance, the maintenance requirements that are typical of this operation may be difficult to accomplish in a remote environment. For example, the surfaces of the cylinders must be maintained at the proper level of "stickiness." If the surfaces are too "sticky," marbles are ejected from the channel between the cylinders. This problem is typically overcome by rubbing the surfaces with waxed paper or oily rags. "Double-gobbing," or the formation of glass gobs that are oversized because of incomplete shearing, is another frequent problem that requires manual correction. In a radioactive hot cell, these maintenance activities would likely be conducted using manipulators. It seems doubtful, however, that these required manipulator activites can be accomplished efficiently enough to ensure satisfactory continuity of operations. 


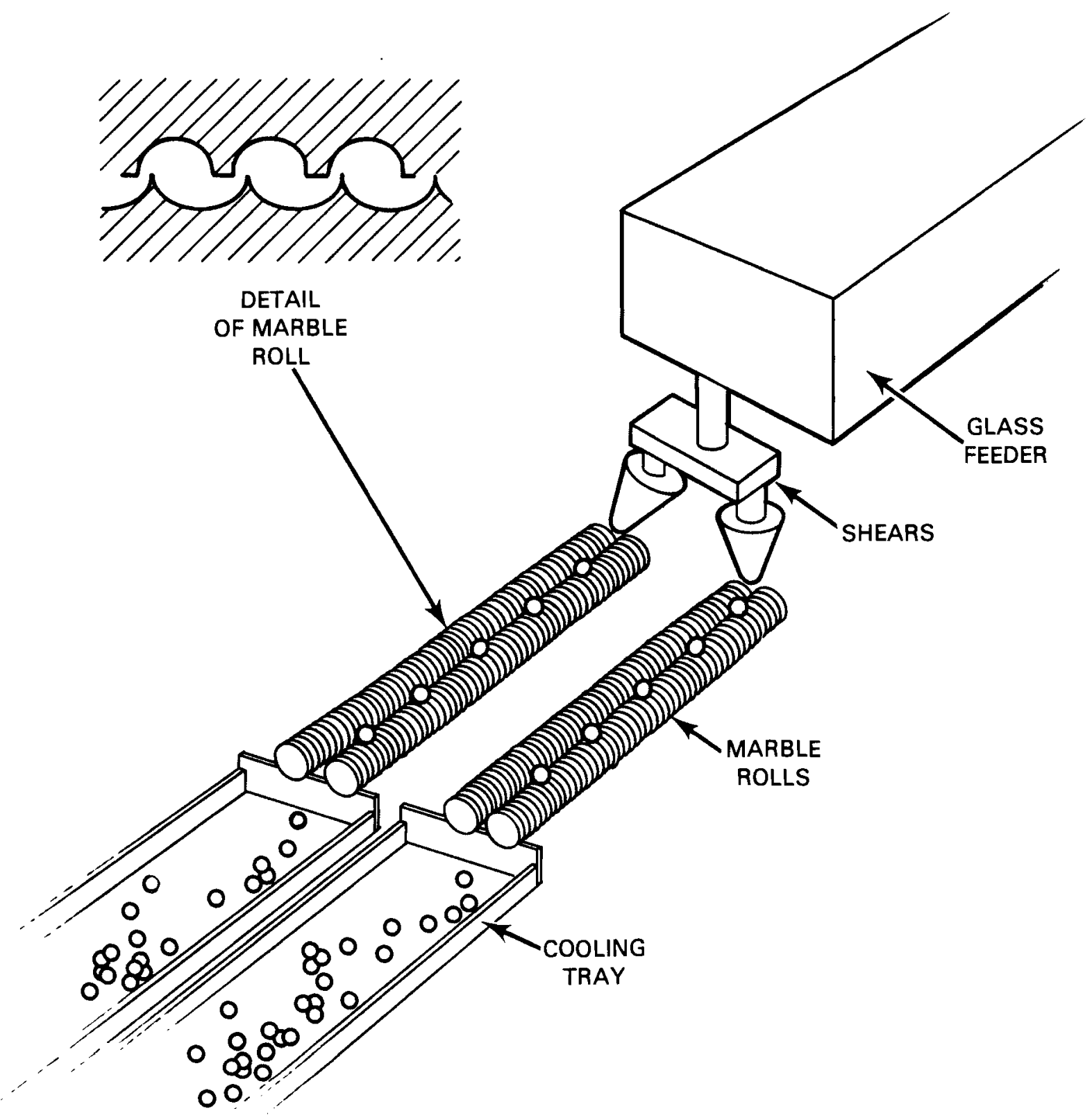

FIGURE 5. Conventional U.S. Marble Machine

A variety of methods exists to make small glass spheres having diameters that are usually less than $1 \mathrm{~mm}$. Although small glass spheres are highly resistant to thermal shock during their production and, therefore, are fairly easy to make, the ratio of the surface area to the mass can be very high. For 
example, on a mass-equivalent basis, typical 0.1 -mm-dia particles have a combined surface area that is 100 times greater than that of typical $10-m m-d i a$ marbles. This is a matter of concern since releases due to leaching are approximately proportional to surface area.

In one method of making small glass beads (U.S. Pat. No. 2600963), molten glass is first poured into cold water to form a frit. The frit is then dried and ground to a desired particle size. The particles are then injected into a burner flame in order to melt the particles and allow surface tension to form them into spheres. Disadvantages of this method include: 1) the limitation that only very small spheres may be formed, 2) the large number of glass filaments formed with beads, and 3) the lack of economy inherent in the remelting of cooled glass frit. This method also involves a high number of mechanical handling steps that would be difficult to accomplish in a remote environment.

In other methods of making small glass beads (U.S. Patent Numbers 3150947,3279905 , and 3293014 ), a stream of molten glass is poured into a high-velocity gas jet mounted transversely to the stream of molten glass. The jet disperses the glass stream into droplets. This method also produces relatively small beads with a large size distribution and requires additional equipment to de-entrain the particles and to remove filaments and nonspherical beads from the product.

U. S. Patent No. 3843340 reports a method of producing larger glass beads ( 1 to $5 \mathrm{~mm} \mathrm{dia).} \mathrm{In} \mathrm{this} \mathrm{method,} \mathrm{beads} \mathrm{are} \mathrm{formed} \mathrm{by} \mathrm{jetting} \mathrm{molten} \mathrm{glass}$ through a small-diameter orifice (e.g., 1/200 to 1/8 of an inch) under a positive pressure (e.g., 1 to 20 psi). Directed outwardly from the nozzle, the jet of glass eventually breaks up into droplets. Under the influence of surface tension, these droplets form into spherical beads having a diameter about twice that of the orifice. The success of this method requires a low viscosity of the glass (preferably in the range of 0.5 to 10 poises) and sufficient time for the newly formed beads to harden while falling through air or some other suitable fluid, such as hot oil. If the beads are relatively large, the required falling height in air can be prohibitively great. This is because of the increased cooling time required to harden the bead and the 
increasing speed of the falling bead as gravity accelerates it. If oil is used as the quenching medium, methods of controlling the temperature of the oil, separating the beads and the oil, and cleaning oil from the beads must be employed. These are complications that reduce the attractiveness of this approach.

A similar quenching approach that eliminates the need for cleaning marbles is reported in U.S. Patent No. 4066430. In this invention, glass beads are dropped into a fluidized dispersion of water in hydrophobic silica. The major part of such a dispersion is water, as much as $96 \%$ by weight. Hence, the dispersion exhibits heat transfer rates approaching that of water. Because the dispersion displays all the outward aspects of fluffy dry powder, surface boiling and thermal shock are reduced. This quenching method was tested at PNL with generally unsatisfactory results, however. Problems included excessive marble breakage and uncorrectable separation of the water and silica dispersion into distinctly liquid and powdery phases. This method of quenching was tried in conjunction with a "gobbing wheel" developed at PNL (Figure 6). In this method, a vibrated, vertically mounted metal wheel with molds machined into its rim is turned under a falling stream of molten glass. Glass gobs are formed in each mold in a manner identical to that of the Corning Glass Works device previously described. Since the glass-gob residence time in this device is substantially less than that in the Corning device, the still-viscous glass marbles that are formed must be properly cooled before they can be stored.

Developers at Eurochemic in Belgium (Vangeel 1980) and later at Rocky Flats Plant (Ledford 1979) have experimented with horizontally mounted wheels, or turntables, to make mint-shaped glass beads. These methods are illustrated in Figures 7 and 8 . In both of these methods, molten glass drips from one or more nozzles onto a slowly rotating turntable. Glass beads are swept off the turntable by a stationary arm. Each nozzle is capable of dripping glass at a rate of about $2 \mathrm{~kg} / \mathrm{h}$. Hence, many nozzles are required to produce beads at 30 to $100 \mathrm{~kg} / \mathrm{h}$ as required to meet the production needs of a typical commercialor defense-waste solidification plant in the United States. Since beads 


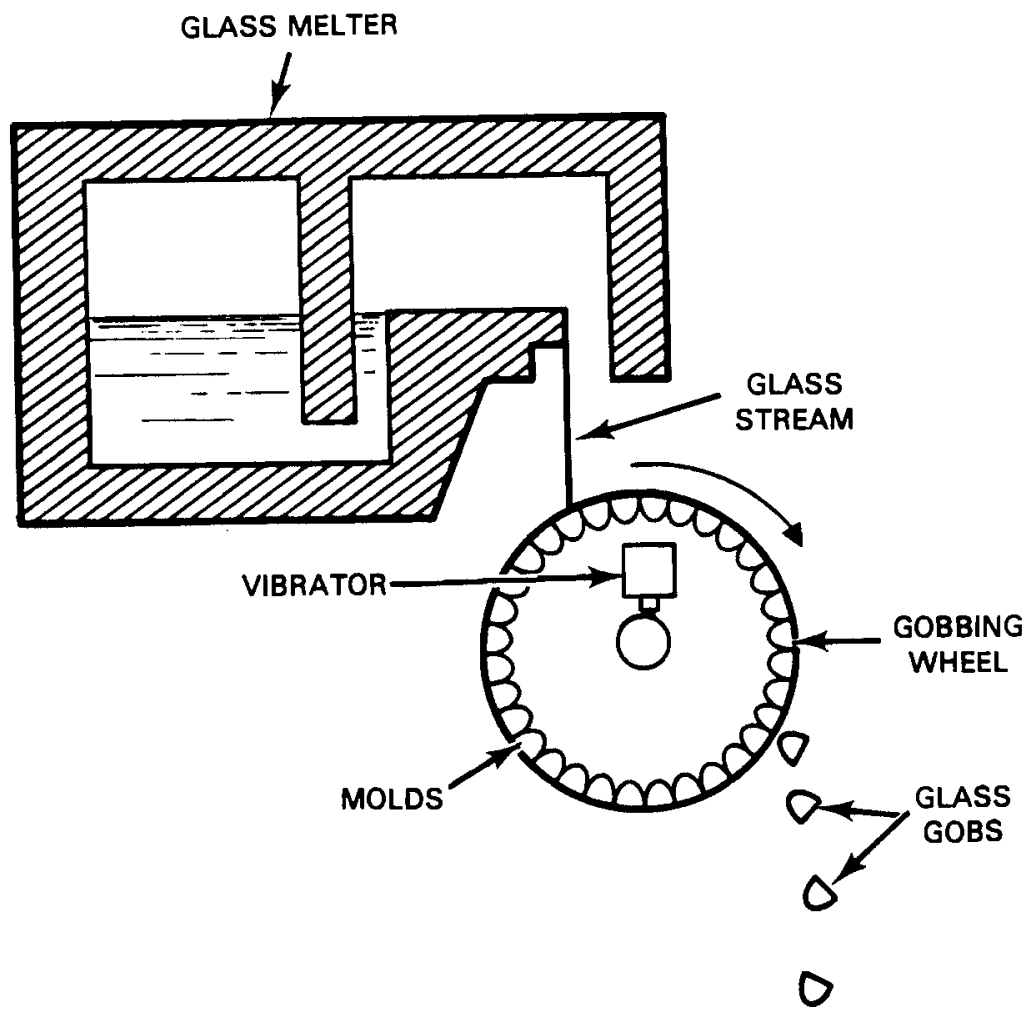

FIGURE 6. PNL Gobbing Whee1

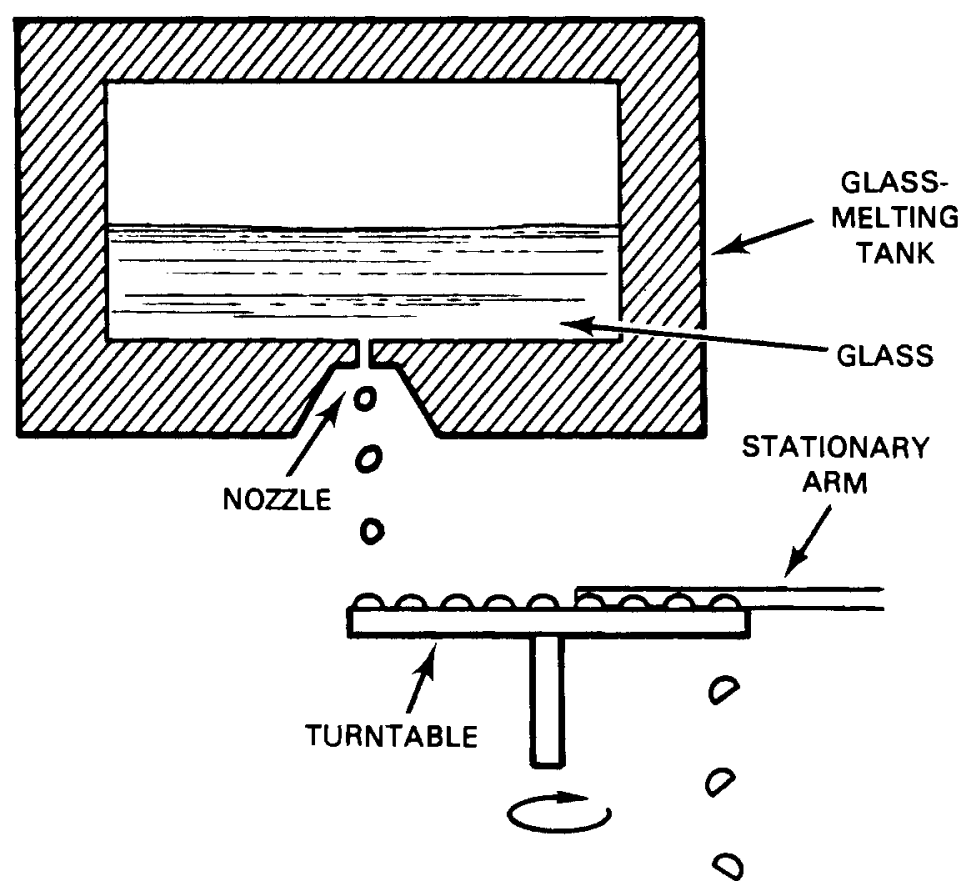

FIGURE 7. Bead-Making Device at Rocky Flats Plant 


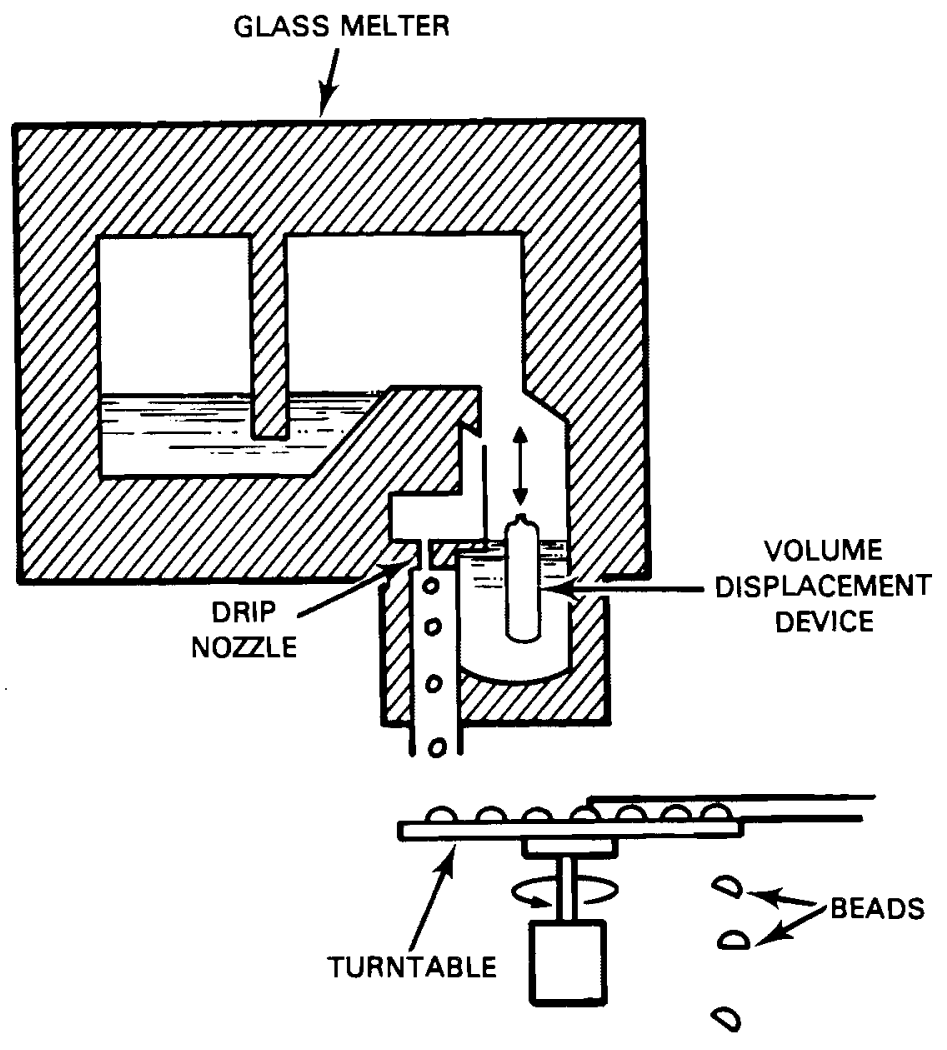

FIGURE 8. Eurochemic Bead-Making Device

formed by this method are not spherical, and since their surfaces are cooled at uneven rates, beads may be more prone to breakage than round marbles. Also, since the nozzle diameters are smal1, they are prone to pluggage and flowrate control problems.

It may be possible to produce spherical marbles from one or more streams of glass poured continuously into molds in a vibrated turntable (Figure 9). Although this concept has not been demonstrated, it may be a fairly straightforward extension of the Corning marble-making technology. The conceptual device would have a circumference that is essentially equal to the length of the Corning device. Hence, the device would be substantially smaller and easier to handle and maintain in a remote operating environment. It is also possible that a single, large vibrator would suffice to break glass strings between molds and impart rotation to the glass gobs. If this approach 


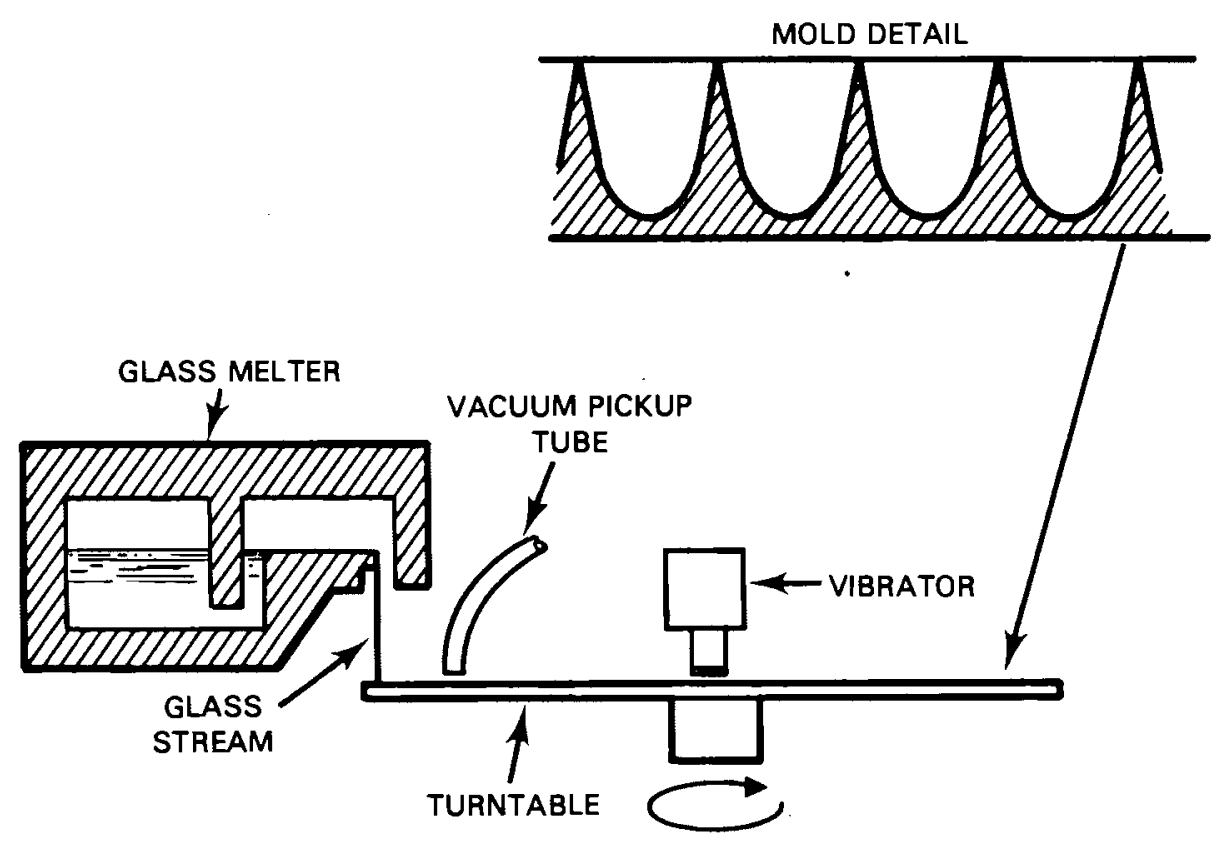

FIGURE 9. Conceptual Marble-Making Device

can be shown to be effective, glass marbles may become an even more attractive alternative for solidifying HLW.

\section{PROCESS FEASIBILITY}

Two studies (E.R. Johnson Associates, Inc. 1980; Nesbitt and Treat 1980) rated the glass marble process as one of the more feasible alternatives for immobilizing HLW. The process, which includes a lead encapsulation step, is depicted in Figure 10. The E. R. Johnson study rated this process fifth in a total of eleven processes evaluated. The four processes rated higher included in-can glass melting, joule-heated glass melting, the glass ceramic process, and the concrete process. All of these processes yield monolithic waste forms, which are less amenable to quality assurance and recycling. The Nesbitt study also rated the glass marble process fifth of nine processes evaluated. The higher-rated processes were the same as those in the $E$. R. Johnson study. In both studies, the reference marble machine is the Corning vibratory device. From the standpoint of ease and reliability of operation 


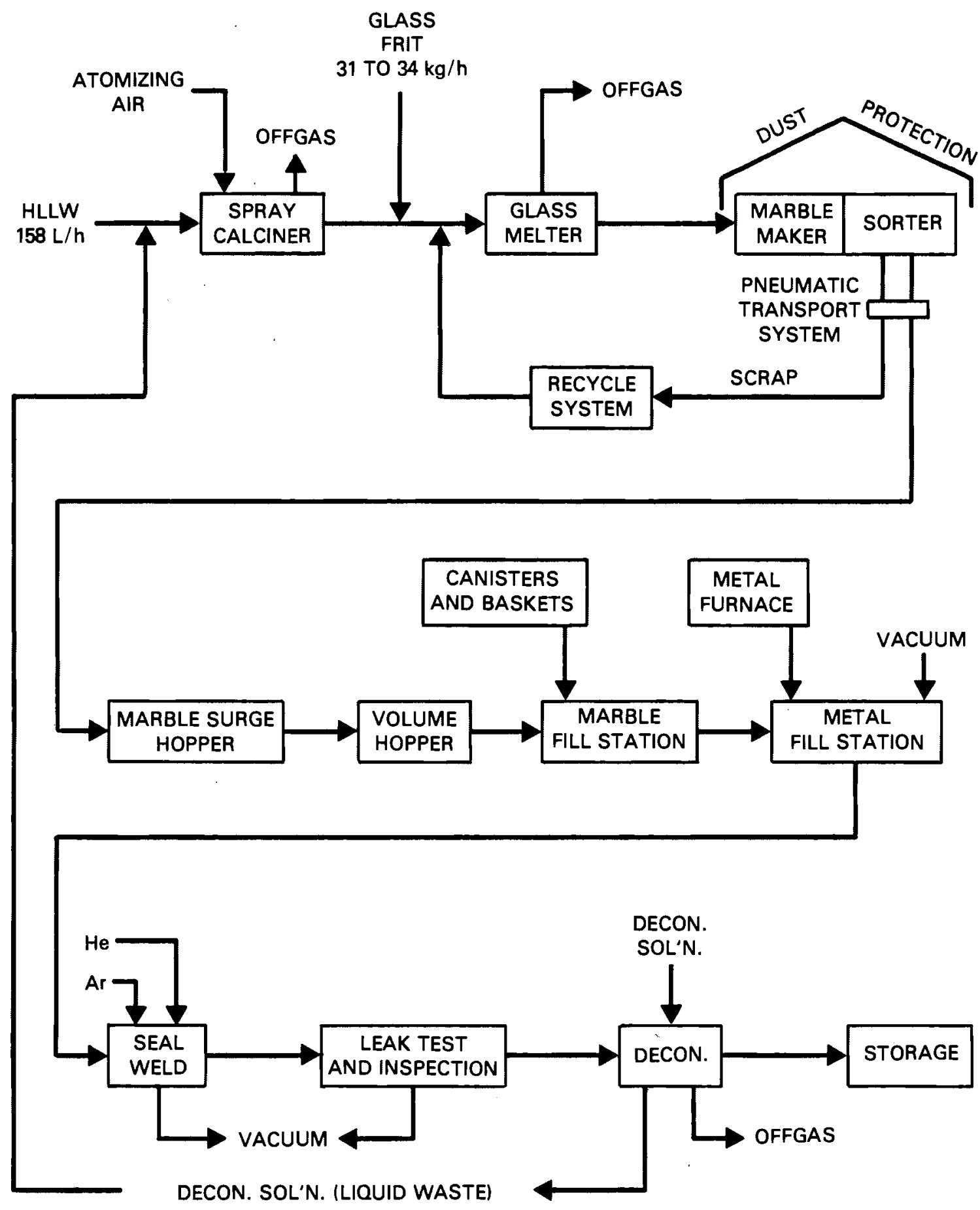

FIGURE 10. Marbles-in-Lead Process 
and marble quality, this device, of all methods yet developed, appears to be the best suited for meeting the production requirements of a United States HLW solidification process. However, the conceptual vibrated turntable device discussed holds promise for reducing the complexity of the process. Its successful development may further enhance the attractiveness of the marble process. 


\section{CERAMIC PELLET PRODUCTION}

Ceramic pellets, like glass marbles, have been developed as inner cores in the multibarrier concept for immobilizing HLW. Two different ceramics have been developed: a silicate-ceramic called "supercalcine" and a sinteredceramic based on the HLW composition at SRP. Production of ceramic pellets requires that liquid wastes first be dried to a fine powder in a spray calciner. This powder may be directly converted to spherical pellets in a disc pelletizer or preconditioned in a pin mixer before pelletization. Then, the pellets are dried and fired at high temperatures to promote densification and the development of the desired physical and chemical properties. Firing devices used at PNL included laboratory muffle furnaces, an in-can sintering furnace, and a vertical sintering kiln. The ceramic pellet process, which includes a step to encapsulate pellets in lead, was assessed as one of the more complex alternatives for immobilizing HLW.

\section{CERAMIC PELLET FORMULATION}

Many ceramic waste-form compositions exist which may be candidates for ceramic pellet production. These include silicate, titanate and alumina-based ceramics. Two different ceramics have been produced at PNL. One, a silicateceramic called "supercalcine" (McCarthy 1977), is made by modifying the composition of liquid HLW with selected additives so that, after drying and firing, an assemblage of mutually compatible crystalline phases is produced. The other ceramic, often referred to as a sintered-ceramic waste form, consists of a blend of crystalline and glassy phases produced by milling selected glass frits and solid nuclear wastes together and firing the agglomerated powders until a sintered body results.

Supercalcine

Supercalcine is an assemblage of refractory and leach-resistant crystalline phases that incorporate the elements present in HLW, e.g., those defined as PW-7 and PW-9 (Table 2). PW-7 waste is representative of the HLW that would be generated at the Allied General Nuclear Services (AGNS) plant in 
TABLE 2. Composition of High-Level Liquid Waste Streams

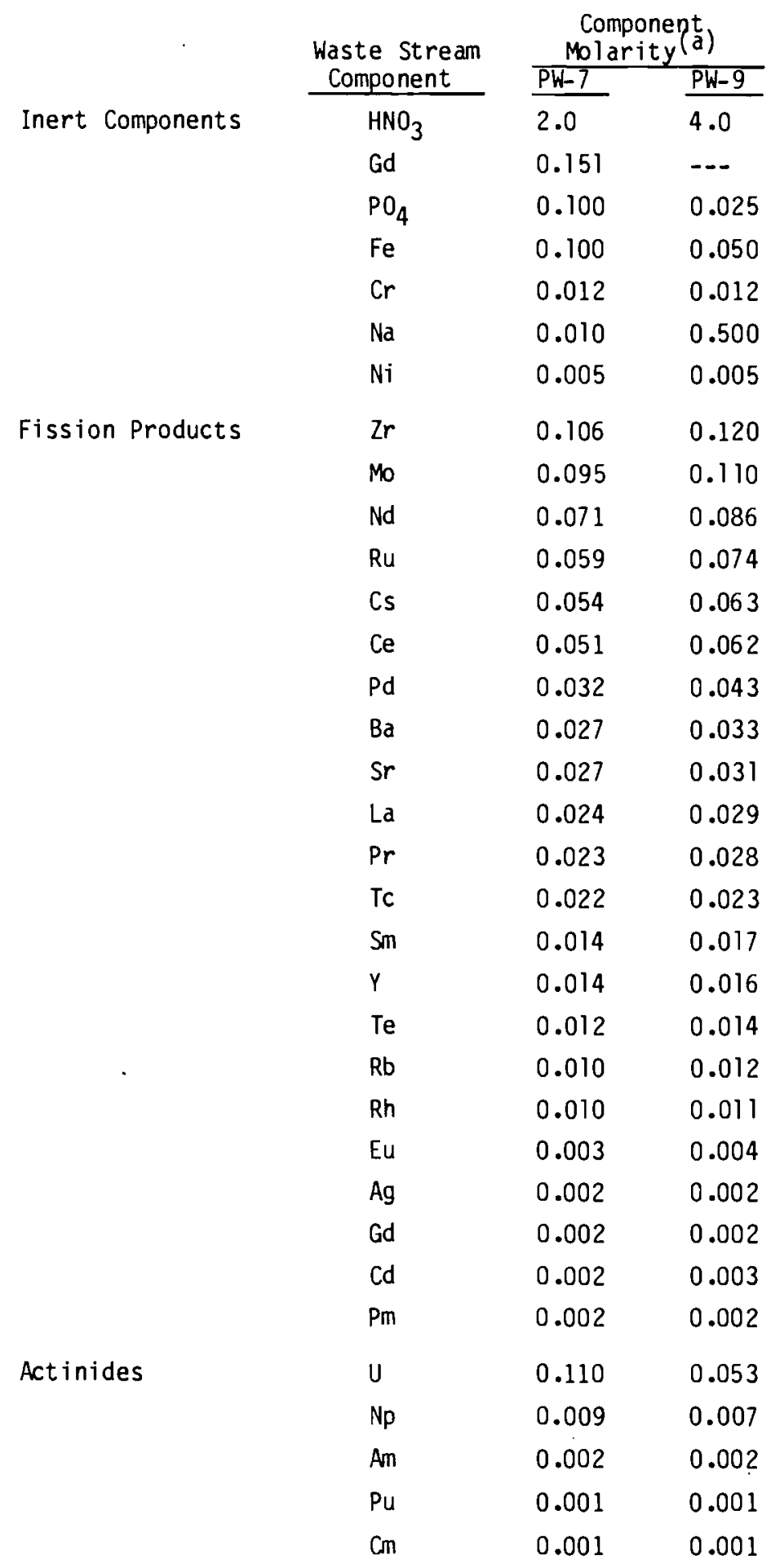

(a) Component molarity based on 378 L/MTU. 
Barnwell, South Carolina. Its composition is based on nuclear fuel burned to a level of 33,000 MWd/MTU. PW- 9 waste is based on fuel burned to a level of 40,000 MWd/MTU, which accounts for its higher fission-product concentration. PW-9 also contains some intermediate-level waste, as is indicated by its higher sodium concentration.

Research on supercalcine was initiated at Pennsylvania State University in 1973 under a contract to PNL. Several criteria established to guide the development of supercalcine formulations were as follows:

- Compatibility. The crystalline phases should be compatible at waste storage temperatures for an indefinitely long period because chemical reactions between two or more of the phases could lead to the formation of undesirable new phases that are less effective for the fixation of the HLW nuclides.

- Thermal Stability. There should be no significant metal or metal oxide volatility losses during firings of several hours' duration at 1000 to $1200^{\circ} \mathrm{C}$, or during prolonged heating at temperatures less than $800^{\circ} \mathrm{C}$. The latter is important for long-term integrity of the HLW solid since volatilized species could migrate under the influence of the thermal gradients in the storage canister and condense in voids or cracks into high-leachability phases.

- Leachability. The leaching resistance should be at least as high as that of the best HLW glasses tested by the standard screening tests.

- Waste Loading. The weight percentage of HLW oxides in supercalcine should be at least $60 \%$. With encapsulation of the coated supercalcine pellet cores in the metal matrix, the waste loading in the canister could then be comparable to the 20 to $30 \mathrm{wt} \%$ typical of HLW glass.

Since no one single crystalline phase is capable of meeting the above criteria, and incorporating all of the 30 to 40 elements of HLW into its structure, supercalcine was developed as a combination of crystalline phases, 
each of which assimilates one or more of the HLW elements into its lattice. Some of the phases that were developed are listed in Table 3. However, other crystalline phases may also be effective in immobilizing nuclear elements, such as the titanate phases developed in the SYNROC concept (Ringwood et al. 1979), or alumina phases developed in tailored ceramics (Morgan et al. 1981).

Several of the elements needed to produce the desired supercalcine phases are not present in HLW in the amounts required. Examples of these are calcium, aluminum, strontium and silicon. These chemicals were normally addęd to the liquid waste as nitrate salts, except for silicon, which was added as a colloidal oxide dispersed in water. The amounts of chemicals added were determined through calculations to produce the desired proportions of supercalcine phases. Developers at Pennsylvania State University have termed this approach "tailor-making" (McCarthy 1977). Several supercalcine formulations have been developed as illustrated in Tables 4 through 6. Supercalcine formulations SPC-2, SPC-4, SPC-4E and SPC-4P are based on the PW-7 composition. Supercalcine SPC-5B and SPC-5P are based on the PW-9 composition. The waste compositions in these formulations deviate somewhat

TABLE 3. Supercalcine Phases

\begin{tabular}{ll}
\multicolumn{1}{c}{ Mineral } & \multicolumn{1}{c}{ Chemical Form } \\
\cline { 1 - 1 } Pollucite & $(\mathrm{Cs}, \mathrm{Rb}, \mathrm{Na}, \mathrm{K}) \mathrm{AlS} \mathrm{Si}_{2} \mathrm{O}_{6}$ \\
Apatite & $(\mathrm{AE})(\mathrm{a}){ }_{2}(\mathrm{RE})(\mathrm{b}){ }_{8}\left(\mathrm{SiO}_{4}\right)_{6} \mathrm{O}_{2}$ \\
Monazite & $(\mathrm{RE}) \mathrm{PO}_{4}$ \\
Scheelite & $(\mathrm{Sr}, \mathrm{Ba}, \mathrm{Ca}) \mathrm{MoO}_{4}$ \\
Sodalite & $\left.(\mathrm{AE})_{2}(\mathrm{NaAlSiO})_{4}\right)_{6}\left(\mathrm{MoO}_{4}\right)_{2}$ \\
Fluorite & $(\mathrm{U}, \mathrm{Ce}, \mathrm{Zr} . . .)_{2} \pm \mathrm{X}$ \\
Tetragonal-Zirconia & $(\mathrm{Zr}, \mathrm{Ce}, \mathrm{RE}, \mathrm{U} . . .)_{2} \mathrm{O}_{2} \mathrm{X}$ \\
Ruthenium Dioxide & $\mathrm{RuO} \mathrm{O}_{2}$ \\
Spinel & $(\mathrm{Fe}, \mathrm{Ni})(\mathrm{Fe}, \mathrm{Cr})_{2} \mathrm{O}_{4}$ and $(\mathrm{Fe}, \mathrm{Cr})_{2} \mathrm{O}_{3}$
\end{tabular}

(a) $A E=$ Alkaline Earth Elements.

(b) $R E=$ Rare Earth Elements. 
TABLE 4. Supercalcine SPC-2 and SPC-4 (as formulated)

\begin{tabular}{|c|c|c|c|}
\hline Component & $\begin{array}{c}\text { SPC-2 } \\
\text { Molarity }\end{array}$ & $\begin{array}{c}\text { SPC-4 } \\
\text { Molarity }\end{array}$ & Chemical Constituent \\
\hline $\mathrm{Ag}$ & -- & 0.002 & $\mathrm{AgNO}_{3}$ \\
\hline $\mathrm{Ba}$ & 0.027 & 0.027 & $\mathrm{Ba}\left(\mathrm{NO}_{3}\right)_{2}$ \\
\hline $\mathrm{Cd}$ & 0.002 & 0.002 & $\mathrm{Cd}\left(\mathrm{NO}_{3}\right)_{2} \cdot 4 \mathrm{H}_{2} \mathrm{O}$ \\
\hline $\mathrm{Cr}$ & 0.012 & 0.012 & $\mathrm{Cr}\left(\mathrm{NO}_{3}\right)_{3} \cdot 9 \mathrm{H}_{2} \mathrm{O}$ \\
\hline Cs & 0.051 & 0.054 & $\mathrm{CsNO}_{3}$ \\
\hline $\mathrm{Fe}(+\mathrm{Ru})$ & $0.100(a)$ & $0.106^{(a)}$ & $\mathrm{Fe}\left(\mathrm{NO}_{3}\right)_{3} \cdot 9 \mathrm{H}_{2} \mathrm{O}$ \\
\hline $\mathrm{H}^{+}$ & 2.000 & 2.000 & $\mathrm{HNO}_{3}(57 \%)$ \\
\hline Mo & 0.095 & 0.095 & $\mathrm{MoO}_{3}$ \\
\hline $\mathrm{Na}$ & 0.010 & 0.010 & $\mathrm{NaNO}_{3}$ \\
\hline $\mathrm{Ni}$ & 0.005 & 0.005 & $\mathrm{Ni}\left(\mathrm{NO}_{3}\right)_{2} \cdot 6 \mathrm{H}_{2} \mathrm{O}$ \\
\hline $\mathrm{PO}_{4}$ & 0.100 & 0.100 & $\mathrm{H}_{3} \mathrm{PO}_{4} \quad(75 \%)$ \\
\hline $\mathrm{Rb}$ & 0.010 & 0.010 & $\mathrm{RbNO}_{3}$ \\
\hline $\mathrm{Ru}$ & 0.006 & 0.006 & $\mathrm{Ru}(\mathrm{NO})\left(\mathrm{NO}_{3}\right)_{3}$ \\
\hline $\mathrm{Sr}$ & 0.027 & 0.027 & $\mathrm{Sr}\left(\mathrm{NO}_{3}\right)_{2}$ \\
\hline $\mathrm{Zr}$ & 0.106 & 0.106 & $\mathrm{ZrO}\left(\mathrm{NO}_{3}\right) \cdot 2 \mathrm{H}_{2} \mathrm{O}$ \\
\hline
\end{tabular}

Rare Earths

\begin{tabular}{|c|c|c|c|}
\hline $\mathrm{Ce}(+U)$ & 0.159 & 0.051 & $\operatorname{REM}(\mathrm{b})$ \\
\hline Gd & $(0.007) \operatorname{REM}^{(b)}$ & 0.144 & $\mathrm{Gd}\left(\mathrm{NO}_{3}\right)_{3} \cdot 6 \mathrm{H}_{2} \mathrm{O}$ \\
\hline $\mathrm{Nd}$ & $(0.065)$ REM & 0.142 & $\mathrm{Nd}\left(\mathrm{NO}_{3}\right)_{3} \cdot 6 \mathrm{H}_{2} \mathrm{O}$ \\
\hline La & 0.091 & $0.027]$ & \\
\hline $\operatorname{Pr}$ & 0.018 & 0.005 & \\
\hline Y & 0.002 & - & \\
\hline $\mathrm{Pm}$ & -- & -- & \\
\hline $\mathrm{Sm}$ & 0.011 & 0.003 & Rare Earth Mixture \\
\hline Dy & & -- & \\
\hline Ho & 0.003 & -- & \\
\hline Eu & & 0.001 & \\
\hline
\end{tabular}

Supercalcine Additives

$\begin{array}{llll}\mathrm{Al} & 0.148 & 0.148 & \mathrm{Al}\left(\mathrm{NO}_{3}\right)_{3} \cdot 9 \mathrm{H}_{2} \mathrm{O} \\ \mathrm{Ca} & 0.209 & 0.062 & \mathrm{Ca}\left(\mathrm{NO}_{3}\right)_{2} \\ \mathrm{Si} & 0.594 & 0.489 & \operatorname{LUDOX}-\mathrm{AS}(\mathrm{C}) \\ \mathrm{Sr} & 0.020 & 0.041 & \mathrm{Sr}\left(\mathrm{NO}_{3}\right)_{2}\end{array}$

(a) $10 \%$ of Ru requirements added as $\mathrm{Ru}$, remainder added as $\mathrm{Fe}$.

(b) REM = Rare Earth Mixture.

(c) Trade name of dupont colloidal silica. 
TABLE 5. Supercalcine SPC-4E and SPC-4P (as formulated)

\begin{tabular}{|c|c|c|c|}
\hline Component & $\begin{array}{c}\text { SPC-4E } \\
\text { Molarity }\end{array}$ & $\begin{array}{l}\text { SPC-4P } \\
\text { Molarity } \\
\end{array}$ & Chemical Constituent \\
\hline $\mathrm{Ag}$ & 0.002 & 0.002 & $\mathrm{AgNO}_{3}$ \\
\hline $\mathrm{Ba}$ & 0.026 & 0.027 & $\mathrm{Ba}\left(\mathrm{NO}_{3}\right)_{2}$ \\
\hline $\mathrm{Cd}$ & 0.002 & 0.002 & $\mathrm{Cd}\left(\mathrm{NO}_{3}\right)_{2} \cdot 4 \mathrm{H}_{2} \mathrm{O}$ \\
\hline Co & $0.010^{(a)}$ & -- & $\mathrm{Co}\left(\mathrm{NO}_{3}\right)_{2}$ \\
\hline $\mathrm{Cr}$ & 0.012 & 0.012 & $\mathrm{Cr}\left(\mathrm{NO}_{3}\right)_{3} \cdot 9 \mathrm{H}_{2} \mathrm{O}$ \\
\hline Cs & -- & 0.054 & $\mathrm{CsNO}_{3}$ \\
\hline $\mathrm{Fe}$ & $0.112^{(b)}$ & 0.100 & $\mathrm{Fe}\left(\mathrm{NO}_{3}\right)_{3} \cdot 9 \mathrm{H}_{2} \mathrm{O}$ \\
\hline $\mathrm{H}^{+}$ & 2.000 & 2.000 & $\mathrm{HNO}_{3}$ \\
\hline K & $.0 .064(c)$ & -- & $\mathrm{KNO} 3$ \\
\hline Mo & 0.114 & 0.095 & $\mathrm{MoO}_{3}$ \\
\hline $\mathrm{Na}$ & 0.010 & 0.010 & $\mathrm{NaNO}_{3}$ \\
\hline $\mathrm{Ni}$ & 0.036 & 0.005 & $\mathrm{Ni}\left(\mathrm{NO}_{3}\right)_{2} \cdot 6 \mathrm{H}_{2} \mathrm{O}$ \\
\hline $\mathrm{PO}_{4}$ & 0.100 & 0.100 & $\mathrm{H}_{3} \mathrm{PO}_{4}$ \\
\hline $\mathrm{Rb}$ & -- & 0.010 & $\mathrm{Rb}\left(\mathrm{NO}_{3}\right)$ \\
\hline Ru & -- & 0.059 & $\mathrm{Ru}(\mathrm{NO})\left(\mathrm{NO}_{3}\right)_{3}$ \\
\hline $\mathrm{Sr}$ & 0.026 & 0.027 & $\mathrm{Sr}\left(\mathrm{NO}_{3}\right)_{2}$ \\
\hline $\mathrm{Zr}$ & 0.104 & 0.106 & $\mathrm{ZrO}\left(\mathrm{NO}_{3}\right)_{2} \cdot 2 \mathrm{H}_{2} \mathrm{O}$ \\
\hline Te & -- & 0.012 & $\mathrm{Te}_{2}$ \\
\hline$P d$ & -- & 0.032 & $\mathrm{Pd}\left(\mathrm{NO}_{3}\right)_{2}$ \\
\hline \multicolumn{4}{|c|}{ Rare Earths } \\
\hline $\mathrm{Ce}$. & 0.066 & 0.051 & $\operatorname{REM}(d)$ \\
\hline Gd & 0.032 & 0.155 & $\mathrm{Gd}\left(\mathrm{NO}_{3}\right)_{3} \cdot 6 \mathrm{H}_{2} \mathrm{O}$ \\
\hline $\mathrm{Nd}$ & 0.119 & 0.071 & $\mathrm{Nd}\left(\mathrm{NO}_{3}\right)_{3} \cdot 6 \mathrm{H}_{2} \mathrm{O}$ \\
\hline Other RE & 0.265 & 0.078 & REM \\
\hline \multicolumn{4}{|c|}{$\begin{array}{l}\text { Supercalcine } \\
\text { Additives }\end{array}$} \\
\hline$A 1$ & 0.148 & 0.148 & $\mathrm{Al}\left(\mathrm{NO}_{3}\right)_{3} \cdot 9 \mathrm{H}_{2} \mathrm{O}$ \\
\hline $\mathrm{Ca}$ & 0.062 & 0.124 & $\mathrm{Ca}\left(\mathrm{NO}_{3}\right)_{2}$ \\
\hline Si & 0.489 & 0.489 & LUDOX $(e)$ \\
\hline$S r$ & 0.041 & 0.041 & $\mathrm{Sr}\left(\mathrm{NO}_{3}\right)_{2}$ \\
\hline
\end{tabular}

(a) Co is a contaminant in the makeup chemicals.

(b) Extra $\mathrm{Fe}$ was added as a stand-in for Ru.

(c) $K$ is a stand-in for Cs and Rb.

(d) $\mathrm{REM}=$ Rare Earth Mixture.

(e) Trade name of duPont colloidal silica. 
TABLE 6. Supercalcine SPC-5B (as formulated)

\begin{tabular}{|c|c|c|c|}
\hline Component & $\begin{array}{l}\text { SPC-5B } \\
\text { Molarity }\end{array}$ & $\begin{array}{c}\text { SPC-5P } \\
\text { Molarity }\end{array}$ & Chemical Constituent \\
\hline $\mathrm{Ag}$ & 0.002 & 0.002 & $\mathrm{AgNO}_{3}$ \\
\hline $\mathrm{Ba}$ & 0.033 & 0.033 & $\mathrm{Ba}\left(\mathrm{NO}_{3}\right)_{2}$ \\
\hline $\mathrm{Cd}$ & 0.003 & 0.003 & $\mathrm{Cd}\left(\mathrm{NO}_{3}\right)_{2} \cdot 4 \mathrm{H}_{2} \mathrm{O}$ \\
\hline $\mathrm{Cr}$ & 0.012 & 0.012 & $\mathrm{Cr}\left(\mathrm{NO}_{3}\right)_{3} \cdot 9 \mathrm{H}_{2} \mathrm{O}$ \\
\hline Cs & 0.063 & 0.063 & $\mathrm{CsNO}_{3}$ \\
\hline $\mathrm{Fe}$ & 0.050 & 0.050 & $\mathrm{Fe}\left(\mathrm{NO}_{3}\right)_{3} \cdot 9 \mathrm{H}_{2} \mathrm{O}$ \\
\hline$H+$ & 4.000 & 4.000 & $\mathrm{HNO}_{3}$ \\
\hline Mo & 0.110 & 0.110 & $\mathrm{MoO}_{3}$ \\
\hline $\mathrm{Na}$ & 0.499 & 0.499 & $\mathrm{NaNO}_{3}$ \\
\hline $\mathrm{Ni}$ & 0.005 & 0.005 & $\mathrm{Ni}\left(\mathrm{NO}_{3}\right)_{2} \cdot 6 \mathrm{H}_{2} \mathrm{O}$ \\
\hline $\mathrm{PO}_{4}$ & 0.025 & 0.025 & $\mathrm{H}_{3} \mathrm{PO}_{4}$ \\
\hline Pd & 0.043 & 0.043 & $\mathrm{Pd}\left(\mathrm{NO}_{3}\right)_{2}$ \\
\hline $\mathrm{Rb}$ & 0.012 & 0.012 & $\mathrm{RbNO}_{3}$ \\
\hline $\mathrm{Rh}$ & 0.011 & -- & $\mathrm{Rh}\left(\mathrm{NO}_{3}\right)_{3} \cdot 2 \mathrm{H}_{2} \mathrm{O}$ \\
\hline $\mathrm{Ru}$ & 0.074 & 0.007 & $\mathrm{Ru}(\mathrm{NO})\left(\mathrm{NO}_{3}\right)_{3}$ \\
\hline $\mathrm{Sr}$ & 0.031 & 0.031 & $\mathrm{Sr}\left(\mathrm{NO}_{3}\right)_{2}$ \\
\hline $\mathrm{Te}$ & 0.014 & 0.014 & $\mathrm{TeO}_{2}$ \\
\hline $\mathrm{Zr}$ & 0.120 & 0.120 & $\mathrm{ZrO}\left(\mathrm{NO}_{3}\right)_{2} \cdot 2 \mathrm{H}_{2} \mathrm{O}$ \\
\hline
\end{tabular}

Rare Earths

$\left.\begin{array}{lll}\hline \text { Ce } & 0.062 & 0.062 \\ \text { Dy } & & 0.002 \\ \text { Eu } & & 0.001 \\ \text { Gd } & 0.008 & 0.006 \\ \text { La } & 0.087 & 0.065 \\ \mathrm{Nd} & 0.067 & 0.086 \\ \text { Pr } & 0.020 & 0.015 \\ \text { Sm } & 0.011 & 0.008 \\ \text { Y } & 0.008 & 0.006\end{array}\right\} \begin{aligned} & \\ & \text { Supercalcine } \\ & \text { Additives }\end{aligned}$

(a) Trademark of duPont colloidal silica. 
from the defined PW-7 and PW-9 compositions due to the high cost of specific chemicals and the inability of radioactive-materials handling in the test facilities at PNL.

Savannah River Plant Waste Ceramic

Ceramic formulations were developed for HLW generated at the SRP for the purpose of producing pelletized ceramic substrates for the application of pyrolytic carbon coatings (Oma et al. 1981). Criteria were established which controlled the development of these ceramic formulations:

- The ceramic should be highly crystalline in its composition.

- The ceramic must have a high waste loading (>60\%) and a high density in order to minimize bulk volume.

- The ceramic must be capable of being manufactured into pellets having a diameter of at least $0.5 \mathrm{~cm}$ to minimize the coating material requirements and to minimize the contribution of the coating to the overall volume.

- The pellets must be attrition resistant during the coating process.

- The ceramic formulation must accommodate variable waste compositions.

- The ceramic must be fired at fairly low temperatures $\left(<1100^{\circ} \mathrm{C}\right)$ to minimize volatility of radioactive species, such as cesium.

- The pellets must be producible in a disc pelletizer and have minimal unacceptable product.

In the development of supercalcine formulations, knowledge of the precise chemical makeup of the waste was required to "tailor-make" the desired crystalline phases. However, in the development of the SRP ceramic, only a knowledge of the approximate waste composition was required. Glass powders were simply added in various proportions to SRP waste powders to: 1) provide crystal-forming elements such as lead, silicon and barium; 2) provide a vitreous phase for promoting mass transport during firing; and 3) bond crystals and amorphous particles together. In this approach, the final 
product consisted of a mixture of vitreous, crystalline, and amorphous solid phases that varied in composition as functions of the waste composition and of the particular glass powder used.

The waste powders used in the SRP ceramic formulations were produced by spray calcining a simulated SRP waste slurry. The composition of the waste powder is shown in Table 7. Higher-than-normal levels of cerium, cesium, neodymium, and strontium are present in the waste powder for tracer purposes in leach testing. Two formulations, MB-1 and MB-2, were developed, and their compositions are shown in Table 8. Of the three glass powders used in the ceramic formulations, Frit-131, was developed at Savannah River Laboratory for

TABLE 7. Composition(a) of Simulated SRP Calcine Powder

\begin{tabular}{lr}
$\begin{array}{c}\text { Component } \\
\text { Oxides }\end{array}$ & \multicolumn{1}{c}{$w t \%$} \\
\cline { 1 - 1 } $\mathrm{Al}_{2} \mathrm{O}_{3}$ & 24.37 \\
$\mathrm{~B}_{2} \mathrm{O}_{3}$ & 0.62 \\
$\mathrm{CaO}$ & 2.65 \\
$\mathrm{Ce}_{2} \mathrm{O}_{3}$ & 0.84 \\
$\mathrm{Cs}_{2} \mathrm{O}$ & 0.46 \\
$\mathrm{Fe}_{2} \mathrm{O}_{3}$ & 41.23 \\
$\mathrm{Li}_{2} \mathrm{O}$ & 0.24 \\
$\mathrm{MgO} \mathrm{MnO}_{2}$ & 0.71 \\
$\mathrm{Na}_{2} \mathrm{O}$ & 11.87 \\
$\mathrm{Na}_{2} \mathrm{SO}_{4}$ & 6.38 \\
$\mathrm{Nd}_{2} \mathrm{O}_{3}$ & 1.45 \\
$\mathrm{NiO}$ & 0.88 \\
$\mathrm{SiO}_{2}$ & 4.51 \\
$\mathrm{SrO}$ & 3.33 \\
& 0.46
\end{tabular}

(a) Composition is based on oxide content. Actual calcine powder contains approximately 15 wt\% water, carbonates, nitrates and other volatile species. 
TABLE 8. Composition of SRP Ceramic Formulations and Glass Powders

- $\quad$ Ceramic Formulations

MB-1 Ceramic

SRP Calcine powder $\quad 70 \%$

Frit 131

Barium metaphosphate $\quad 5 \%$

MB-2 Ceramic

SRP calcine powder $\quad 70 \%$

Lead borosilicate frit $30 \%$

- Glass Powders

Frit 131

\begin{tabular}{|c|c|}
\hline $\mathrm{B}_{2} \mathrm{O}_{3}$ & $14.7 \%$ \\
\hline $\mathrm{La}_{2} \mathrm{O}$ & $0.5 \%$ \\
\hline $\mathrm{Li}_{2} \mathrm{O}$ & $5.7 \%$ \\
\hline Mg0 & $2.0 \%$ \\
\hline $\mathrm{Na}_{2} \mathrm{O}$ & $17.7 \%$ \\
\hline $\mathrm{SiO}_{2}$ & $57.9 \%$ \\
\hline $\mathrm{TiO}_{2}$ & $1.0 \%$ \\
\hline $\mathrm{ZrO}_{2}$ & $0.5 \%$ \\
\hline \multicolumn{2}{|c|}{ Barium Metaphosphate Frit } \\
\hline $\mathrm{BaO}$ & $52 \%$ \\
\hline $\mathrm{P}_{2} \mathrm{O}_{5}$ & $48 \%$ \\
\hline \multicolumn{2}{|c|}{ Lead Borosilicate Frit } \\
\hline $\mathrm{B}_{2} \mathrm{O}_{3}$ & $15 \%$ \\
\hline Pb0 & $50 \%$ \\
\hline $\mathrm{SiO}_{2}$ & $35 \%$ \\
\hline
\end{tabular}

producing glass from SRP waste; the lead borosilicate frit is used for binding grinding media together in the production of grinding wheels; and the barium metaphosphate is used in the enameling industry. Final MB-1 and MB-2 compositions, after firing, are shown in Table 9. 
TABLE 9. SRP Ceramic Pellet Compositions After Firing

\begin{tabular}{|c|c|c|}
\hline \multirow{2}{*}{$\begin{array}{l}\text { Component } \\
\text { Oxides }\end{array}$} & \multicolumn{2}{|c|}{ 0xide Weight Percent } \\
\hline & MB-1 Ceramic & MB-2 Ceramic \\
\hline $\mathrm{Al}_{2} \mathrm{O}_{3}$ & 16.88 & 17.01 \\
\hline $\mathrm{B}_{2} \mathrm{O}_{3}$ & 4.31 & 4.14 \\
\hline $\mathrm{BaO}$ & 2.99 & 0.09 \\
\hline $\mathrm{CaO}$ & 2.01 & 2.07 \\
\hline $\mathrm{Ce}_{2} \mathrm{O}_{3}$ & 0.61 & 0.59 \\
\hline $\mathrm{Co}_{2} \mathrm{O}_{3}$ & 0.02 & -- \\
\hline $\mathrm{Cr}_{2} \mathrm{O}_{3}$ & -- & 0.06 \\
\hline $\mathrm{Cs}_{2} \mathrm{O}$ & 0.28 & 0.20 \\
\hline $\mathrm{Fe}_{2} \mathrm{O}_{3}$ & 27.92 & 26.19 \\
\hline $\mathrm{Gd}_{2} \mathrm{O}_{3}$ & -- & 0.02 \\
\hline $\mathrm{La}_{2} \mathrm{O}_{3}$ & 0.14 & 0.02 \\
\hline $\mathrm{Li}_{2} \mathrm{O}$ & 1.76 & 0.20 \\
\hline $\mathrm{MgO}$ & 1.01 & 0.50 \\
\hline $\mathrm{MnO}_{2}$ & 8.49 & 7.85 \\
\hline $\mathrm{MoO}_{3}$ & 0.02 & 0.02 \\
\hline $\mathrm{Na}_{2} \mathrm{O}$ & 10.08 & 7.15 \\
\hline $\mathrm{Na}_{2} \mathrm{SO}_{4}$ & $0.80^{(a)}$ & 0.75 \\
\hline $\mathrm{Nd}_{2} \mathrm{O}_{3}$ & 0.69 & 0.63 \\
\hline $\mathrm{NiO}$ & 3.17 & 3.08 \\
\hline $\mathrm{P}_{2} \mathrm{O}_{5}$ & 0.84 & -- \\
\hline Pb0 & -- & 14.24 \\
\hline $\mathrm{RuO}_{2}$ & -- & 0.22 \\
\hline $\mathrm{Sb}_{2} \mathrm{O}_{3}$ & -- & 0.26 \\
\hline $\mathrm{SiO}_{2}$ & 17.29 & 14.23 \\
\hline Sro & 0.39 & 0.33 \\
\hline $\mathrm{TiO}_{2}$ & 0.30 & 0.13 \\
\hline $\mathrm{ZrO}_{2}$ & -- & 0.02 \\
\hline & 100.0 & 100.0 \\
\hline
\end{tabular}

(a) Estimated value. 
High-level liquid wastes must be dried to a powder before they can be converted to a final, dense ceramic form. One device which has been developed for drying liquid nuclear wastes is a spray calciner (see Figure 11). Both

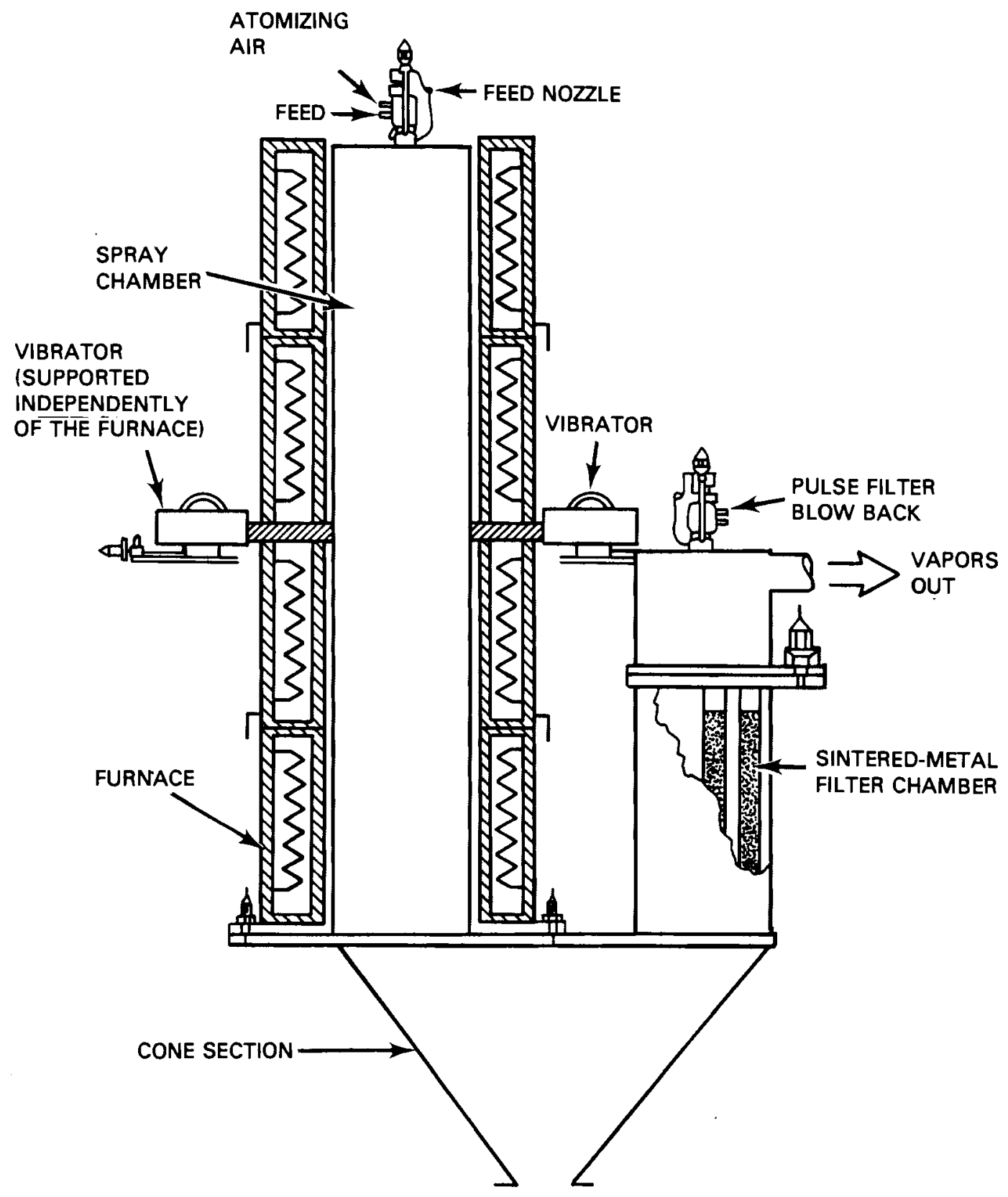

FIGURE 11. PNL Spray Calciner 
supercalcine and SRP waste formulations were dried in this device. The major component of a spray calciner is a heated chamber into which liquid wastes are sprayed. Air is injected with the liquid wastes, which atomizes the waste into fine droplets. As the droplets travel through the heated chamber (wall temperatures are typically $800^{\circ} \mathrm{C}$ ), they are rapidly dried to a fine powder. This powder falls through a cone at the base of the calciner into a collection vessel. Some of the powder is entrained by the atomizing air and steam to a filter chamber and collects on the outside of filter tubes. This powder is periodically removed by air pulsed inside of the filter tubes.

The spray calciner is attractive for converting $H L W$ to a powder because of its:

- inherent simplicity;

- ability to retain semivolatile radionuclides;

- low offgas volume;

- ability to process virtually all waste compositions;

- insensitivity to process and waste compositional changes;

- production of an active, readily processed powder.

During the past 20 years, extensive testing of spray calciners has been conducted with a variety of HLW compositions (Larson 1980), including actual radioactive wastes. Liquids have been converted to powders at rates ranging from 1 to $500 \mathrm{~L} / \mathrm{h}$ in spray calciners at PNL. Powders that result from spray calcination typically contain 10 to 15\% water, nitrates, carbonates and other volatile species. The mean particle diameter is $\sim 10 \mu \mathrm{m}$ and has a surface area of 10 to $20 \mathrm{~m}^{2} / \mathrm{g}$. The powder is somewhat cakey, very dusty, hygroscopic and exhibits loose and vibrated bulk densities of $\sim 0.6$ and $\sim 0.9 \mathrm{~g} / \mathrm{cm}^{3}$, respectively.

\section{DISC PELLETIZER}

The disc pelletizer has been found effective in converting powders to spherical pellets that range in diameter from 0.2 to $2.0 \mathrm{~cm}$ (Lukacs et al. 1979). The disc pelletizer is a simple device that consists of a rotating, inclined pan into which powder and a liquid binder are fed at controlled rates (Figure 12). Liquid binder is sprayed onto the surfaces of pellets so that, 


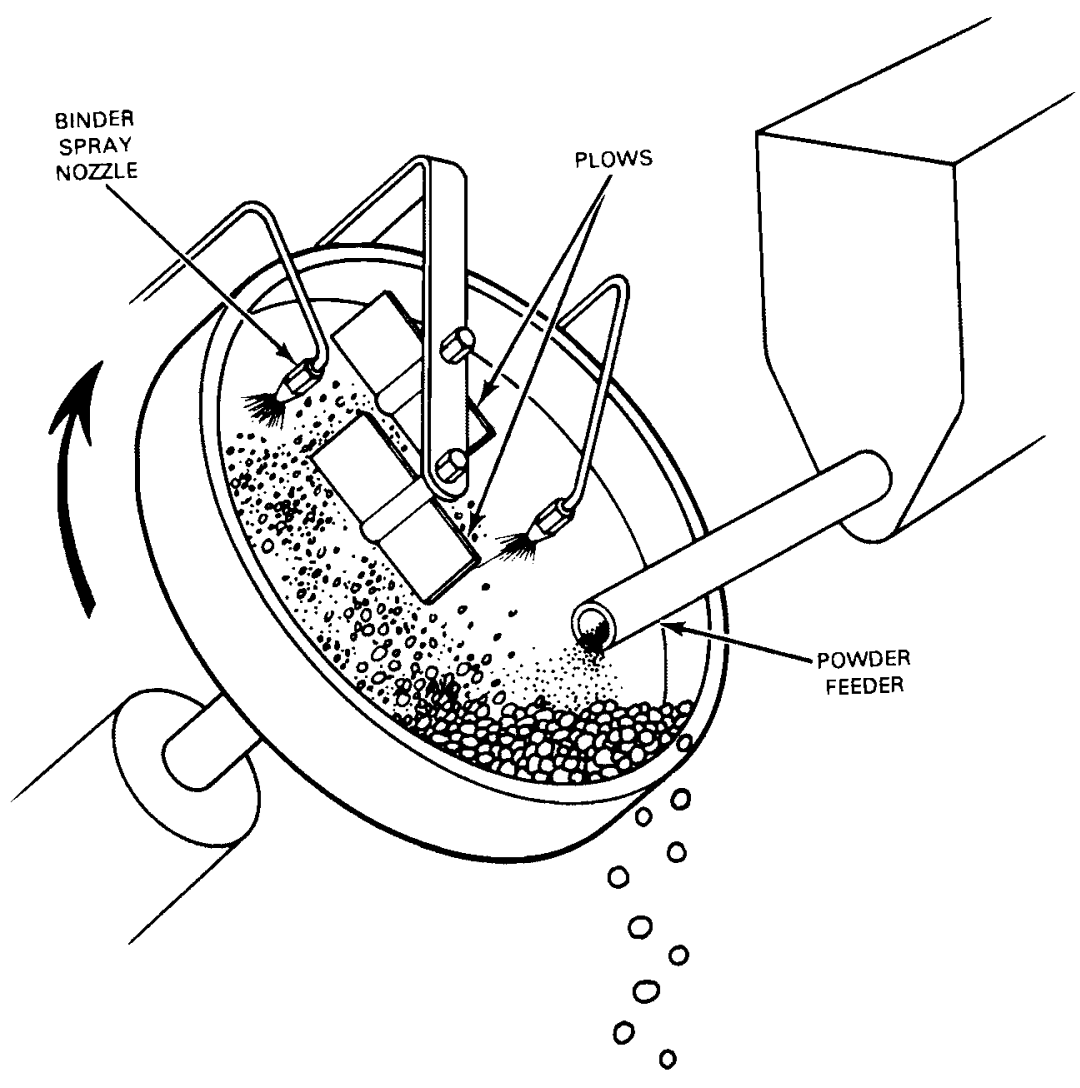

FIGURE 12. Disc Pelletizer

as the pellets tumble and rotate, they accumulate dry powder in a snowballing fashion. Larger pellets gravitate to the top of the pan, spilling over the lip of the pan and leaving the smaller pellets behind to grow further. Factors such as the pan angle and speed of rotation control pellet size. The pan in the disc pelletizer at PNL has a diameter of $40 \mathrm{~cm}$ and is $9 \mathrm{~cm}$ deep. The unit can convert powders to pellets at rates as high as $60 \mathrm{~kg} / \mathrm{h}$. Fixed blades or "plows" are positioned to prevent the excessive accumulation of wet powders in the pan and to aid in establishing desired pellet flow patterns. However, a thin layer of wet powder in the base of the pan is required, to ensure proper pellet tumbling.

Both the supercalcine and the SRP waste powders were converted to pellets in the PNL disc pelletizer. In the case of supercalcine SPC-4E and SRP waste 
formulations, cornstarch was mixed with the dry powders before pelletizing to provide pellets with a suitable unfired strength. Up to 5 wt\% cornstarch was used. Cornstarch was selected as a dry binder because it burns cleanly away during sintering and does not cause any apparent reduction of oxides in the pellets. However, suitably strong supercalcine SPC-2 and SPC-4 pellets were produced without cornstarch additions. In all pellets, water served as the liquid binder. Water requirements varied between 20 and $30 \%$ of the unfired pellet weight. In the SRP sintered-ceramic formulations, the waste powder, the glass powder and the cornstarch were milled together for 2 min in a small disc mill prior to pelletizing. In the case of supercalcine SPC-4E formulation, the cornstarch was simply mixed with the calcine powder without milling.

\section{PIN MIXER}

Some waste powders have been found difficult to handle because of poor flow characteristics and/or excessive dustiness. The pin mixer (Figure 13) has been shown to be effective in converting powders to dust-free particles which are $<1 \mathrm{~mm}$ dia and essentially free-flowing. The pin mixer consists of a horizontal drum containing an axially mounted, rotating shaft. "Pins" or spikes extend radially from the shaft to within $\sim 2 \mathrm{~mm}$ of the drum wall. The shaft and pin assembly rotate at a high speed ( $900 \mathrm{rpm})$, which causes powders and a liquid binder to become intimately mixed and agglomerated into smal 1 particles. Powder and the liquid binder are added at one end of the pin mixer and are discharged at the other end as agglomerates after only a few seconds of mixing.

The pin mixer at PNL, whose drum is $31 \mathrm{~cm} \mathrm{dia}$ and $69 \mathrm{~cm}$ long, and is capable of agglomerating powders at a rate of up to $300 \mathrm{~kg} / \mathrm{h}$. Although the product particles are too small for use in the multibarrier concept, they do serve as an excellent feed material for disc pelletizing; e.g., powders for making supercalcine SPC-4E were conditioned in the pin mixer before pelletizing. 


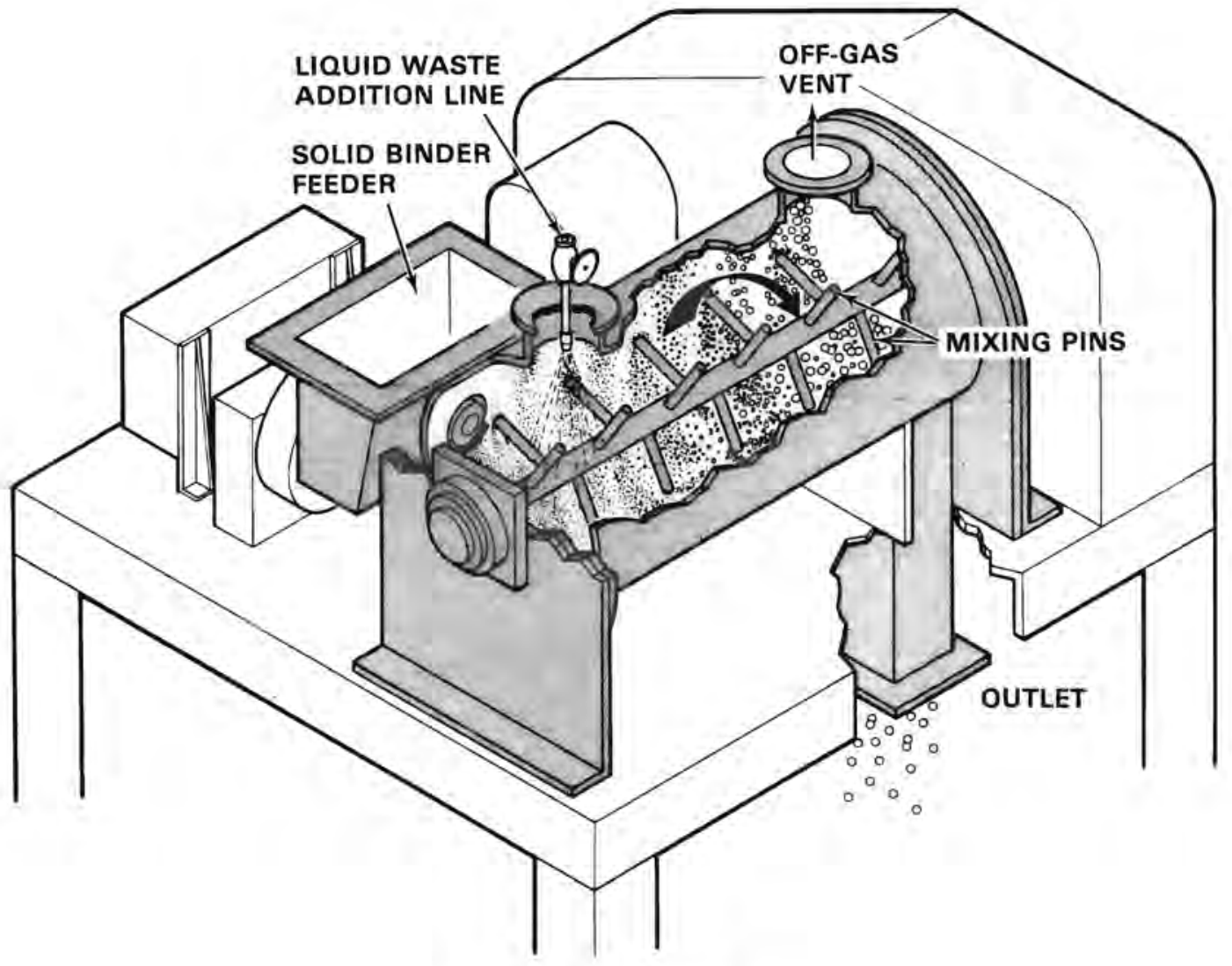

FIGURE 13. Pin Mixer

\section{SINTERING METHODS}

HLW pellets produced in the disc pelletizer must be dried and then sintered to remove volatile components and cause densification. In general, densification increases with rising temperatures until partial melting prevents the free release of evolving gases. At this point, bubbles are formed, and bloating of the pellet may occur. At still higher temperatures, the pellet may foam or simply slump into a puddle. Obviously, it is desirable to control the sintering temperature at or below the point of which maximum pellet denisty is achieved. Soaking time, or the time at which pellets are held at the maximum temperature, is an important consideration since further pellet densification occurs.

The rate at which pellets are sintered may also be important. Green pellets that are very dense and/or contain a high volatile content may rupture 
if the internal pressure caused by escaping gases exceeds the tensile strength of the pellet. The reducing or oxidizing potential of the sintering atmosphere may also be important. If insufficient oxygen exists to burn away the cornstarch binder, for example, reduction of some oxides to metals may result. An undesirable side effect of sintering is the evolution of semivolatile radionuclides, such cesium and ruthenium. These volatiles must be recovered and recycled.

Three different devices were used to sinter supercalcine and SRP pellets: 1) muffle furnace, 2) in-can sintering furnace, and 3) vertical sintering kiln.

\section{Laboratory Muffle Furnace}

Tests to establish pellet sintering parameters were conducted in a small laboratory muffle furnace. This furnace was heated in a manner that represented the operation of a tunnel kiln, a common device for firing commercial ceramics. A tunnel kiln contains carts loaded with materials to be fired which are moved through progressively hotter zones until a final sintering temperature is reached. After soaking, the carts are moved through cooler zones and are finally withdrawn from the kiln.

Supercalcine SPC-2 and SPC-4 pellets were sintered in the laboratory muffle furnace. They were heated at a rate of $200^{\circ} \mathrm{C} / \mathrm{h}$ to maximum temperatures of $1175^{\circ} \mathrm{C}$ and $1230^{\circ} \mathrm{C}$, respectively. After 2 hours of soaking, the pellets were cooled at a rate of $200^{\circ} \mathrm{C} / \mathrm{h}$. Supercalcine pellets were sintered in containers made of dense alumina, zirconia and platinum. Sintering between pellets resulted in the forming of weak, intra-pellet bonds, which were easily broken by hand.

\section{In-Can Sintering Furnace}

Batch sintering of pellets can be accomplished by heating pellets in a large can. The pellets require separation from one another by filling the space between pellets with a granular, inert-carrier material such as alumina or zirconia. The carrier material tends to bridge over the pellets as they shrink during sintering. This prevents the pellets from being compressed into 
an agglomerated mass when the pellets are softened at high firing temperatures. Sintering rates of individual pellets are somewhat uneven because pellets near the middle of the can are insulated by pellets and carrier near the walls of the can.

Supercalcine SPC-4E pellets were sintered in a $41 \mathrm{~cm}$ dia $\times 210 \mathrm{~cm}$ Incone $1^{{ }_{-}} 601$ can with the use of $\sim 60$ mesh alumina as the carrier material. Air was slowly purged into the bottom of the can to provide oxygen for burning the cornstarch binder until a temperature of $600^{\circ} \mathrm{C}$ was reached. The pellets were heated at a maximum rate of $200^{\circ} \mathrm{C} / \mathrm{h}$ to a temperature of $1200^{\circ} \mathrm{C}$. All of the pellets were soaked at this temperature for at least $4 \mathrm{~h}$, although pellets near the can walls were soaked for $8.5 \mathrm{~h}$. After cooling, some difficulty was encountered in removing pellets from the can because of pellet-to-pellet and carrier-to-pellet contact bonding; however, agglomerated pellets and adhering alumina particles were successfully broken apart by tumbling.

Vertical Sintering Kiln

A vertical sintering kiln was originally developed at PNL to sinter nuclear fuel pellets (Nesbitt and Ryer 1980). The vertical sintering kiln (Figure 14) has a high throughput-to-size ratio and is compatible with modular construction concepts for ease of remote maintenance. The kiln consists of a vertically mounted, heated muffle through which pellets and carrier material travel. Pellets mixed with a carrier (such as granular alumina) are added to the top of the muffle. This mixture falls, by gravity, through heated zones and eventually is discharged out the bottom of the muffle. The carrier material is separated from the pellets and is recycled. Gases are introduced at the bottom of the muffle to control the atmosphere in the furnace. Gases are drawn to the top of the muffle and into an offgas processing system. In the PNL design, the muffle is heated with molybdenum heating elements which enable sintering to temperatures as high as $1700^{\circ} \mathrm{C}$ under reducing conditions. Sintering under oxidizing conditions would require a different heating system and would be limited to temperatures of $\sim 1300^{\circ} \mathrm{C}$.

(®) Inconel-601 is the trademark of International Nickel Company. 


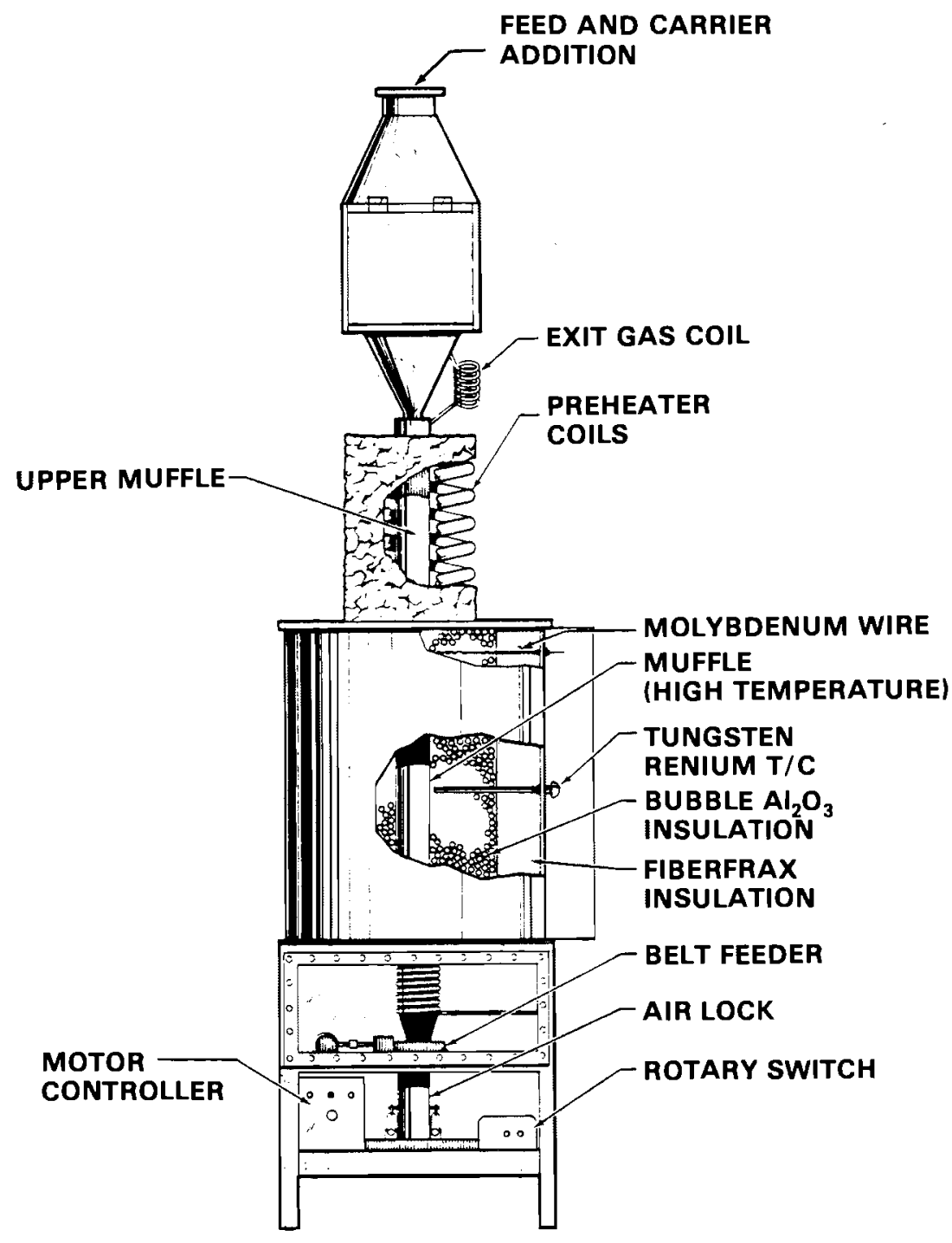

FIGURE 14. Vertical Sintering Kiln

Sintering tests conducted on SPC-4E pellets were generally successful. Approximately $5 \mathrm{~L}$ of these pellets were mixed with an equal amount of granular alumina. This mixture was exposed to $1200^{\circ} \mathrm{C}$ for 2 hours in the kiln in an Ar$5 \% \mathrm{H}_{2}$ atmosphere. This treatment resulted in pellets that were densified to 30 to $40 \%$ of their original volume. However, in one test in which a carrier was not used, pellets agglomerated into a hard mass that required shutting down the furnace and rodding to remove the mass. 
SRP MB-1 and MB-2 pellets were also processed in the vertical sintering kiln. However, after sintering at a temperature range of $900^{\circ} \mathrm{C}$ to $950^{\circ} \mathrm{C}$ for 2 hours in an $\mathrm{Ar}-5 \% \mathrm{H}_{2}$ atmosphere, there was no apparent reduction in average pellet size. Some pellets were embedded with grains of the alumina carrier and others showed signs of partial melting.

\section{PROCESS FEASIBILITY}

In a recent study (E. R. Johnson 1980), the ceramic pellet process was assessed as one of the more complex alternatives for immobilizing HLW. The process is depicted in Figure 15. Of the 11 processes studied, the ceramic process ranked eighth in feasibility. Processes assessed as having a lower feasibility included: 1) the ceramic pellet process with a pellet coating step; 2) the supercalcine hot-isostatic pressing process; and 3 ) the SYNROC hot isostatic pressing process. 


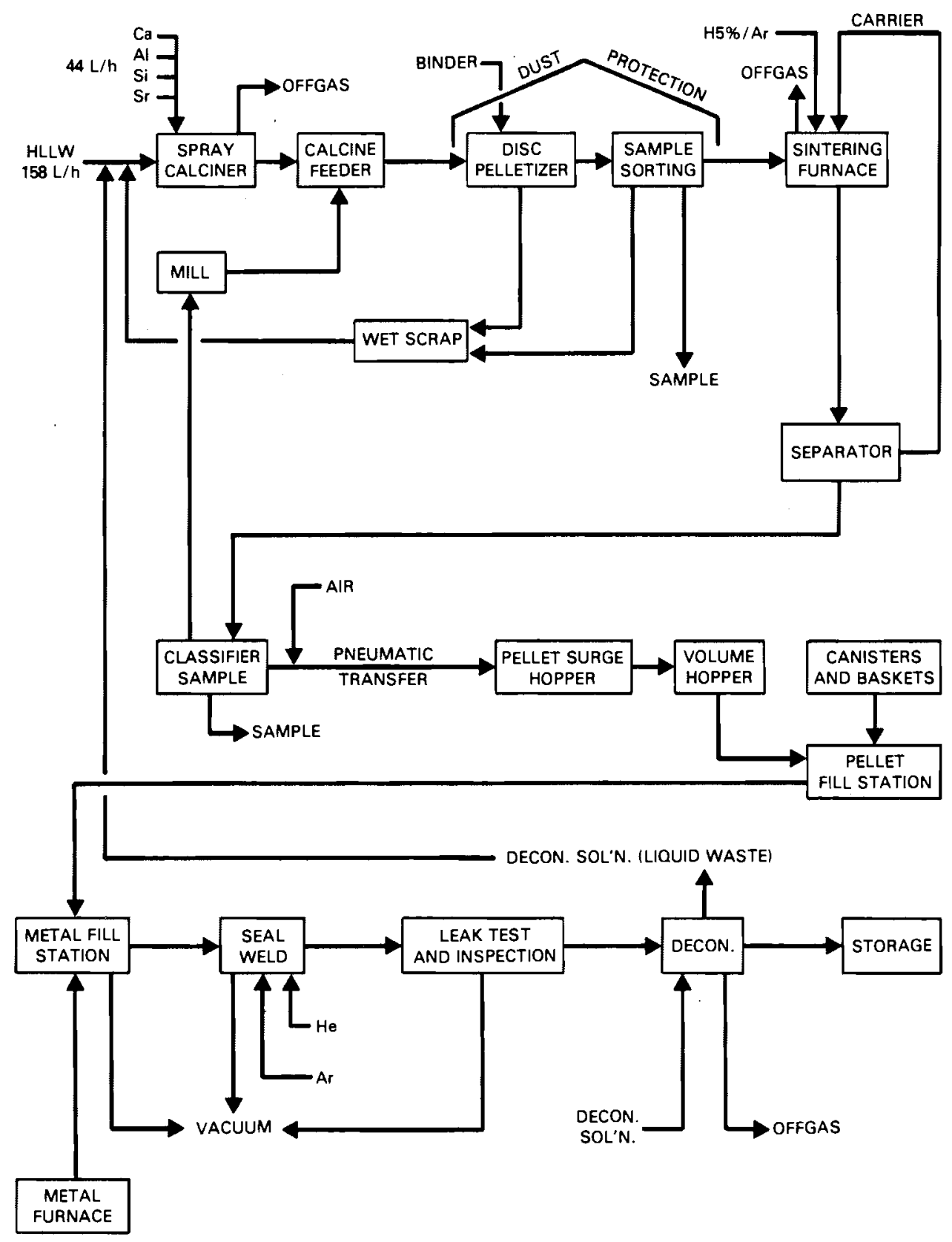

FIGURE 15. Supercalcine Pellets in Lead Matrix Process 
Detailed characterization of the glass marbles and ceramic pellets as used in various multibarrier concepts is presented elsewhere (Rusin 1978; Rusin 1979; Oma 1981; Wald 1981). Since the purpose of this report is to document the process development of glass marble and ceramic-pellet waste forms, only an overview of product characterization will be presented in this section.

\section{SINTER ING BEHAVIOR}

Sintering behavior only applies to ceramic-pellet production. Heat treatment or sintering of "green" ceramic pellets as produced directly from the disc pelletizer is conducted to accomplish two purposes. First, consolidation takes place due to reaction of components within the pellet, and shrinkage occurs. The porosity of the pellet is reduced during this densification process. The other objective of sintering is to produce an assemblage of stable crystalline phases. In the case of supercalcine, specific additives are used to produce a "tailored" ceramic waste form containing specific silicate-based crystalline phases. For the MB-1 and MB-2 formulations, glass frit was added to aid in consolidation without any specific tailoring of crystalline phases.

The sintering behavior of supercalcine was determined primarily by coldpressing cylindrical pellets of calcined material at pressures ranging from 4,000 to 20,000 psi and sintering in laboratory muffle furnaces. Density and relative crystalline content as identified by $x$-ray diffraction (XRD) analysis was used to characterize the samples. An alternative method that incorporates a bulk-vibrated sample with a "green density" more typical of disc-pelletized material was also used. For the bulk test, alumina crucibles were filled and vibrated to produce powder samples with green densities comparable to that of pelletized supercalcine $\left(0.90\right.$ to $\left.1.15 \mathrm{~g} / \mathrm{cm}^{3}\right)$. These crucible samples were then sintered in laboratory muffle furnaces. 
The sintering behavior of supercalcine SPC-2 and SPC-4 has been well documented (Rusin 1978) and is illustrated in Figure 16. From these results, sintering schedules for disc-pelletized material were established to be 2 hours at $1175^{\circ} \mathrm{C}$ for $S P C-2$ pellets and 2 hours at $1230^{\circ} \mathrm{C}$ for $S P C-4$. The

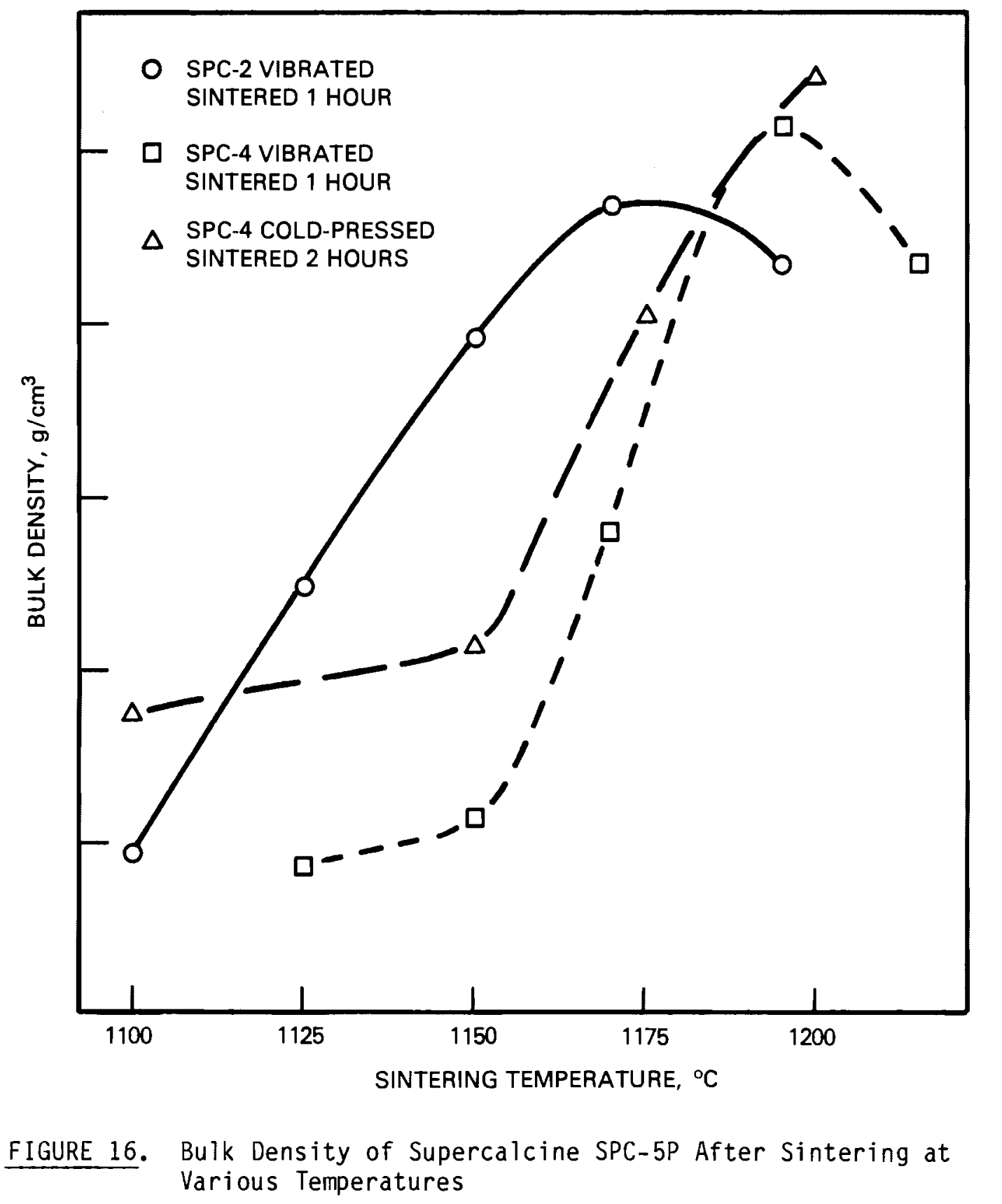


sintering behavior of SPC-4P and SPC-4E is similar to that of SPC-4, and 2 hours at $1200^{\circ} \mathrm{C}$ was determined as an appropriate sintering schedule for coldpressed samples of these formulations. In SPC-4P sintered at $1200^{\circ} \mathrm{C}$ for longer time periods, some changes were noted in the relative intensities of a number of phases. For example, a $32 \%$ decrease in pollucite concentration was observed after 6 hours at $1200^{\circ} \mathrm{C}$ and a $92 \%$ decrease after 24 hours. The decrease in the pollucite phase may indicate that the pollucite had reacted with excess $\mathrm{SiO}_{2}$ and $\mathrm{Al}_{2} \mathrm{O}_{3}$ to form a non-crystalline aluminosilicate phase.

The sintering behavior of supercalcine SPC-5E and SPC-5P is similar but differed slightly from that of the SPC-4 formulations in that sintering temperatures were shifted lower by $\sim 50^{\circ} \mathrm{C}$ (Figure 17). Maximum density was

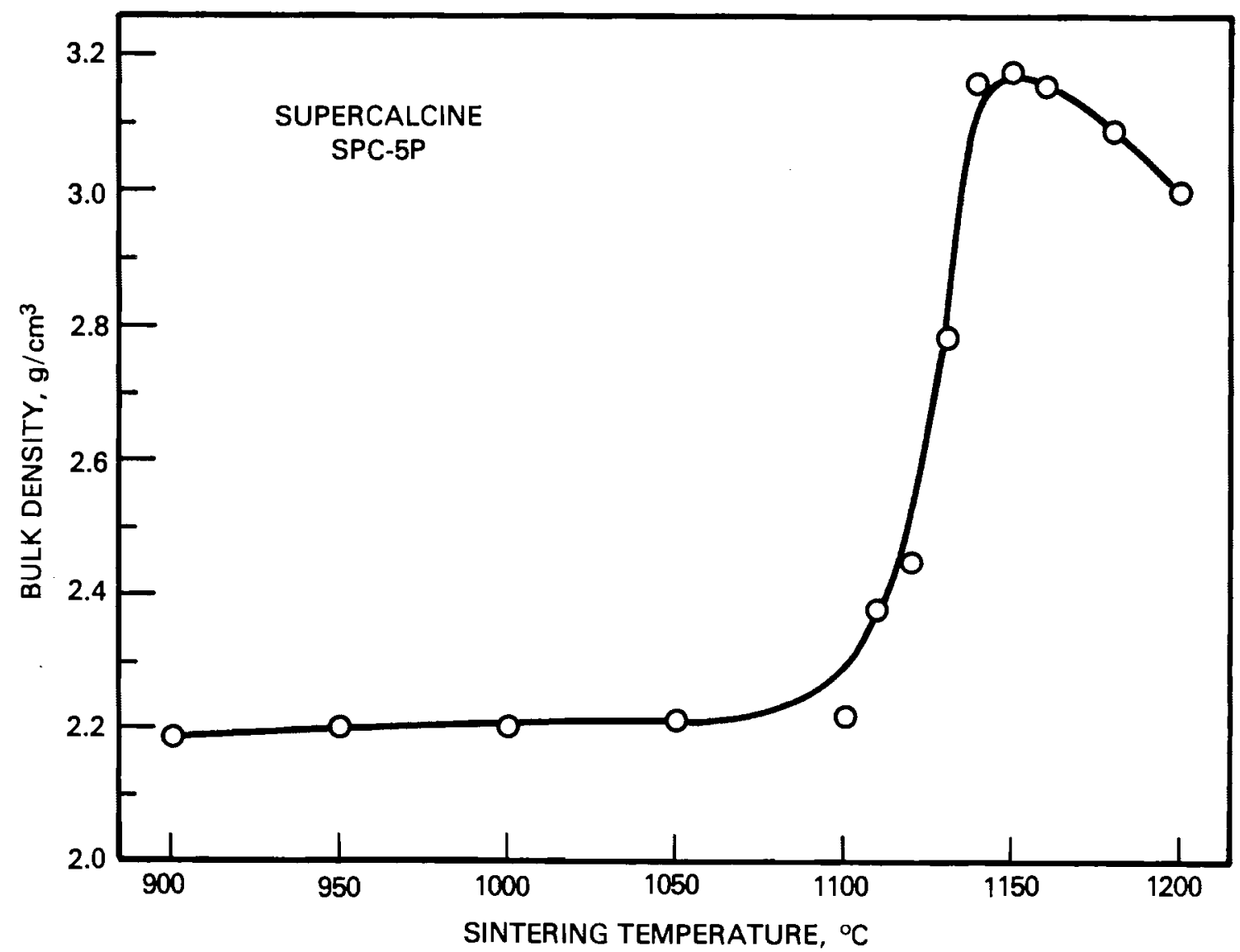

FIGURE 17. Bulk Density of Supercalcine SPC-5P After Sintering for $2 \mathrm{~h}$ at Various Temperatures 
obtained at $1150^{\circ} \mathrm{C}$ instead of $1200^{\circ} \mathrm{C}$ as for $S P C-4$. Thus, 2 hours at $1150^{\circ} \mathrm{C}$ is the recommended sintering schedule for SPC-5 formulations. The crystalline phase content of SPC-5 is also a function of sintering time and temperature as shown in Figures 18 and 19 for the SPC-5P formulation. Above $1100^{\circ} \mathrm{C}$, there is a decrease in pollucite, which may again indicate formation of an amorphous aluminosilicate phase. There is a decrease in both pollucite and sodalite with sintering time at $1100^{\circ} \mathrm{C}$.

The sintering behavior of the calcine/frit mixtures for MB-1 and MB-2 formulations was not studied in the same detail as for supercalcine since the objective was to sinter a pellet at minimum temperatures that was durable enough to be coated in a fluidized bed. Processing temperatures no greater than $800^{\circ} \mathrm{C}$ were desired to minimize cesium volatility. To determine appropriate sintering schedules, pellets made from various mixtures of calcine and frit were heated from 1 to $4 \mathrm{~h}$ at $600^{\circ} \mathrm{C}$ to $1200^{\circ} \mathrm{C}$. Sintering temperatures above $900^{\circ} \mathrm{C}$ were necessary to produce high-quality pellets. The highest quality pellets were produced between $1000^{\circ} \mathrm{C}$ and $1200^{\circ} \mathrm{C}$. Formulations were adjusted to obtain good quality pellets at approximately $1000^{\circ} \mathrm{C}$. Final sintering schedules were 2 hours at $1000^{\circ} \mathrm{C}$ for $\mathrm{MB}-1$ and 2 hours at $1060^{\circ} \mathrm{C}$ for $\mathrm{MB}-2$.

\section{BULK PROPERTIES}

Bulk properties of simulated waste-glass marbles and sintered ceramic pellets are summarized in Table 10. The glass marbles contain very little porosity $(<1 \%)$ and are limited in use to temperatures near their softening point $\left(\sim 450^{\circ} \mathrm{C}\right.$ to $\left.600^{\circ} \mathrm{C}\right)$. Disc-pelletized ceramic pellets contain from 20 to $40 \%$ porosity, which is characteristic of this agglomeration method. Coldpressed and sintered and hot-pressed ceramics are denser with porosities less than $10 \%$. Since the ceramic products were sintered at high temperatures, they are capable of much higher use temperatures $\left(1000^{\circ} \mathrm{C}\right.$ to $\left.1200^{\circ} \mathrm{C}\right)$ than the glass marbles. 


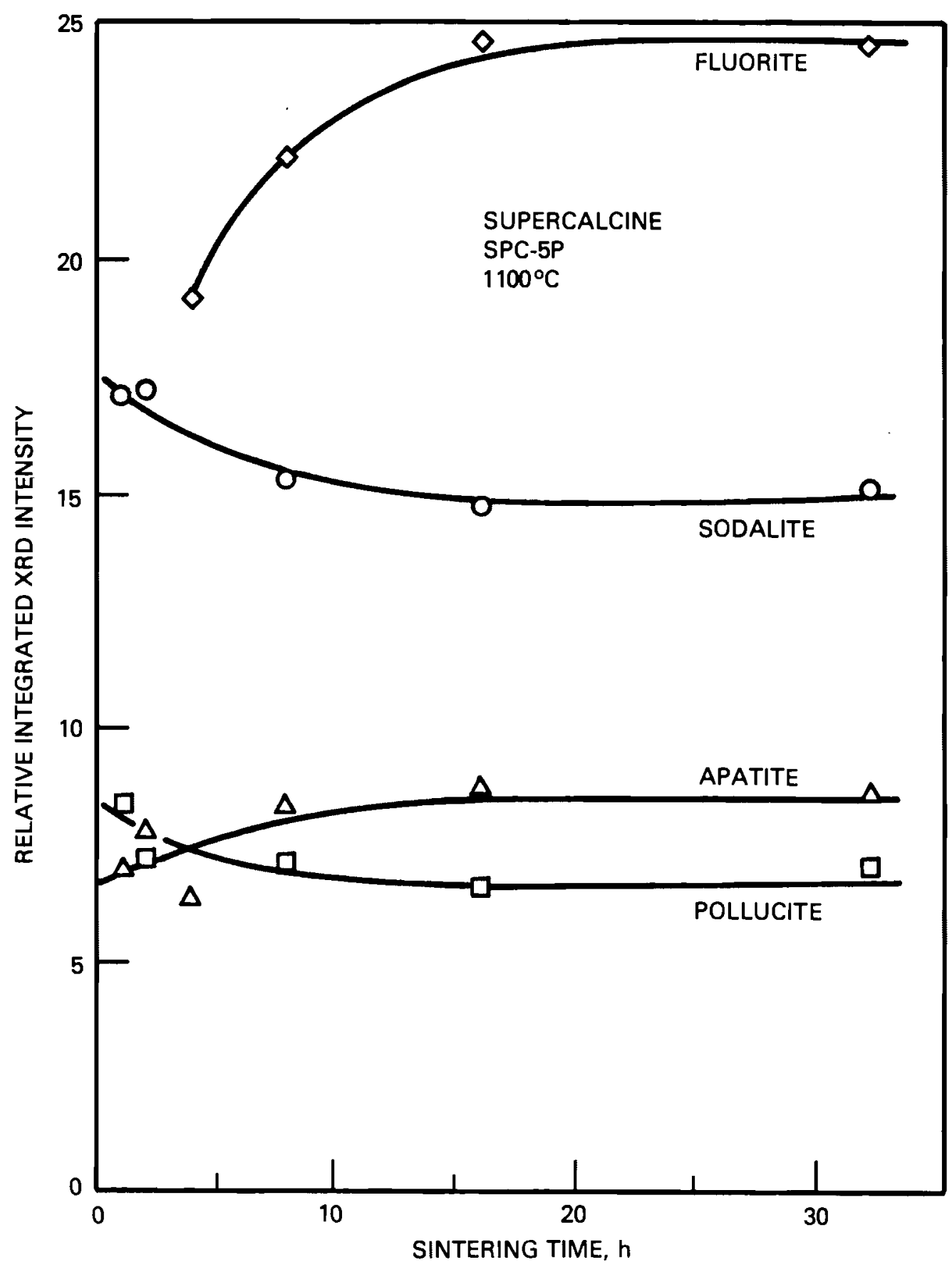

FIGURE 18. Relative Crystalline Phase Content for Supercalcine (SPC-5P) Sintered at $1100^{\circ} \mathrm{C}$ for Various Time Periods 


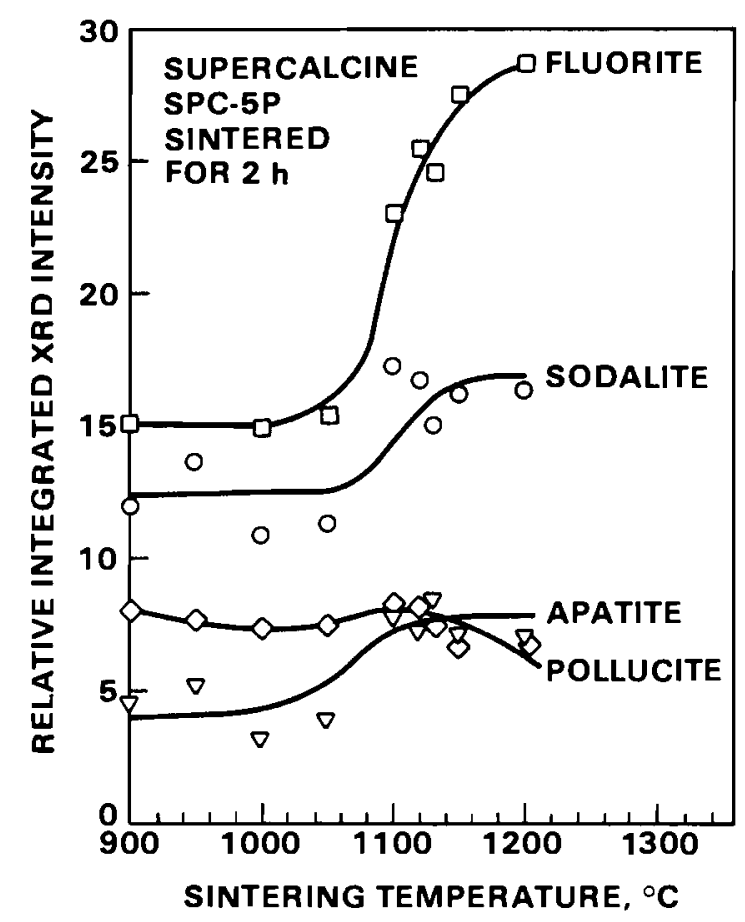

FIGURE 19. Relative Crystalline Phase Content for Supercalcine (SPC-5P) Versus Sintering Temperature

MICROSTRUCTURE AND PHASE ANALYSIS

The glass marbles are 96 to $100 \%$ vitreous with less than $1 \%$ porosity. Typical crystalline phases found in 76-68 glass are $\mathrm{CeO}_{2}, \mathrm{RuO}_{2}$ and $\mathrm{Pd}$ metal (Ross 1978). Crystals of the spinel structure ( $\mathrm{Ni}, \mathrm{Mn})(\mathrm{Fe}, \mathrm{Cr})_{2} \mathrm{O}_{4}$ are often found in simulated TDS-211 waste glass marbles. Micrographs of typical wasteglass marbles, along with pelletized ceramics, are given in Figure 20.

The disc-pelletized and sintered-ceramic waste forms contain 20 to $40 \%$ porosity. Phase characterization data for typical ceramic waste-form pellets are shown in Table 11 along with that for glass marbles for comparison. In addition to the specific tailored crystalline phases, an amorphous phase often exists in the ceramic waste forms. As discussed in sintering behavior, crystalline content is often a function of sintering schedule. 
TABLE 10. Bulk Properties of Simulated Waste Glass Marbles and Ceramic Pellet Waste Forms

\begin{tabular}{|c|c|c|c|c|}
\hline Material & $\begin{array}{c}\text { Bulk } \\
\text { Densit,y, } \\
\mathrm{g} / \mathrm{cm}^{3} \\
\end{array}$ & $\begin{array}{c}\text { Porosity, } \\
\%\end{array}$ & $\begin{array}{l}\text { Thermal } \\
\text { Expansjon, } \\
{ }^{\circ} \mathrm{C}^{-1}\end{array}$ & $\begin{array}{l}\text { Maximum Use } \\
\text { Temperature, } \\
{ }^{\circ} \mathrm{C}\end{array}$ \\
\hline ICM-11 Glass Marble & 3.4 & $<1 \%$ & -- & 550 \\
\hline 76-68 Glass Marble & 2.98 & $<1 \%$ & $9.0 \times 10^{-6}$ & 500 \\
\hline TDS-211 Glass Marble & 2.75 & $<1 \%$ & $6.7 \times 10^{-6}$ & 450 \\
\hline SPC-2 Pellet(a) & 3.8 & $22 \%$ & -- & 1175 \\
\hline SPC-2 Pellet(b) & 3.8 & $22 \%$ & -- & 1100 \\
\hline SPC-2 Pellet (c) & 4.88 & $<1 \%$ & -- & 200 \\
\hline SPC-4 Pellet(a) & 3.6 & $21 \%$ & -- & 1200 \\
\hline SPC-4 Pellet (b) & 4.21 & $6 \%$ & -- & 1200 \\
\hline SPC-4 Pellet (c) & 4.47 & $2 \%$ & $9.5 \times 10^{-6}$ & 1200 \\
\hline SPC-4P Pellet $(b)$ & 4.06 & $11 \%$ & -- & 1200 \\
\hline SPC-4E Pellet(a) & 3.9 & $14 \%$ & $9.3 \times 10^{-6}$ & 1200 \\
\hline$S P C-4 E$ Pellet $(b)$ & 4.02 & $11 \%$ & -- & 1200 \\
\hline SPC-5B Pellet $(b)$ & 2.89 & N.D. & -- & 1150 \\
\hline SPC-5P Pellet (c) & 3.15 & N.D. & -- & $<1150$ \\
\hline $\mathrm{MB}-1$ Pellet (a) & 2.69 & $22 \%$ & $12.5 \times 10^{-6}$ & 1000 \\
\hline MB-2 Pellet(b) & 3.22 & $20 \%$ & $11.5 \times 10^{-6}$ & 1060 \\
\hline
\end{tabular}

(a) Disc pelletized

(b) Cold pressed

(c) Hot pressed

IMPACT RESISTANCE

Impact-resistance and crush-strength measurements have been conducted on a few of the consolidated waste forms. Impact resistance was determined by measuring the amount of fines $\leqslant 37 \mu \mathrm{m}$ that were produced after application of an impact energy of $217 \mathrm{~J}$ (Bunnell 1979). For TDS-211 glass marbles, $6 \pm 3 \%$ fines $\leqslant 37 \mu \mathrm{m}$ were produced from an impact energy of $217 \mathrm{~J}$. Similar tests on $76-68$ glass marbles produced $\sim 9.5 \%$ fines $\leqslant 37 \mu \mathrm{m}$. 


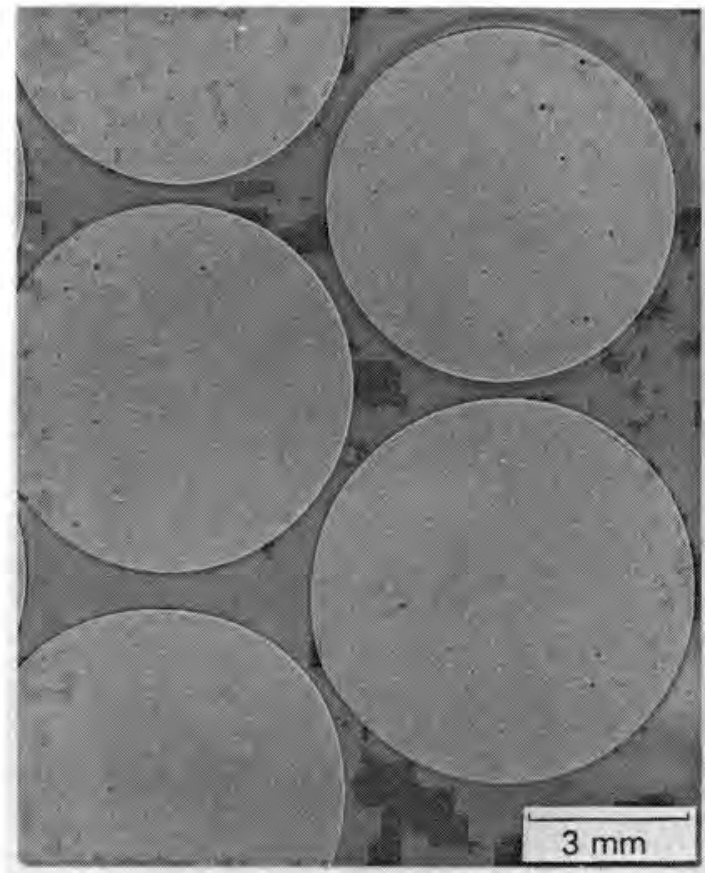

76-68

GLASS MARBLE

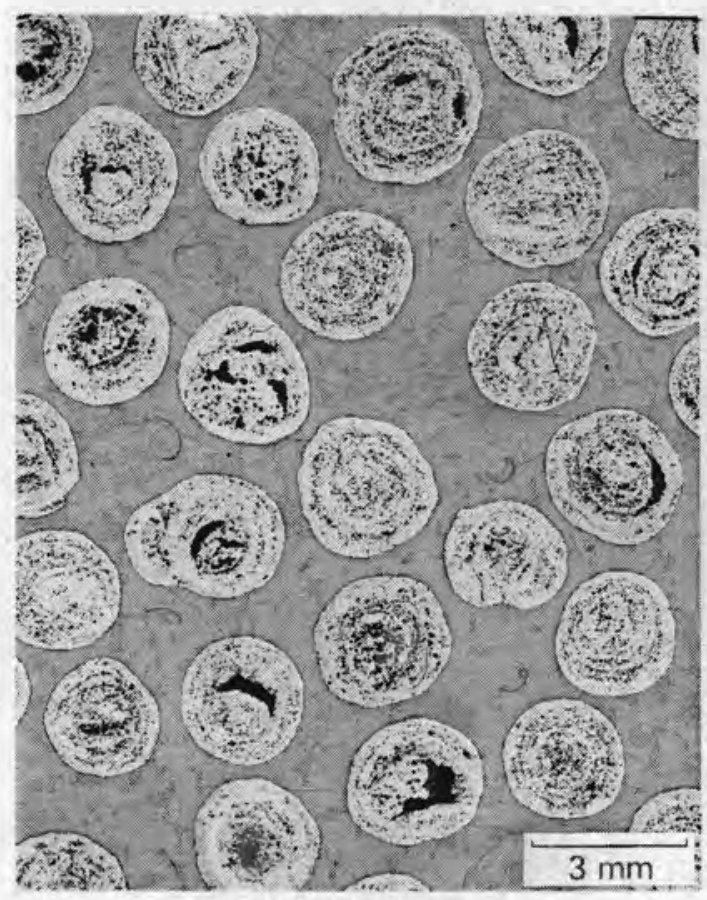

DISC-PELLETIZED

SUPERCALCINE SPC-4

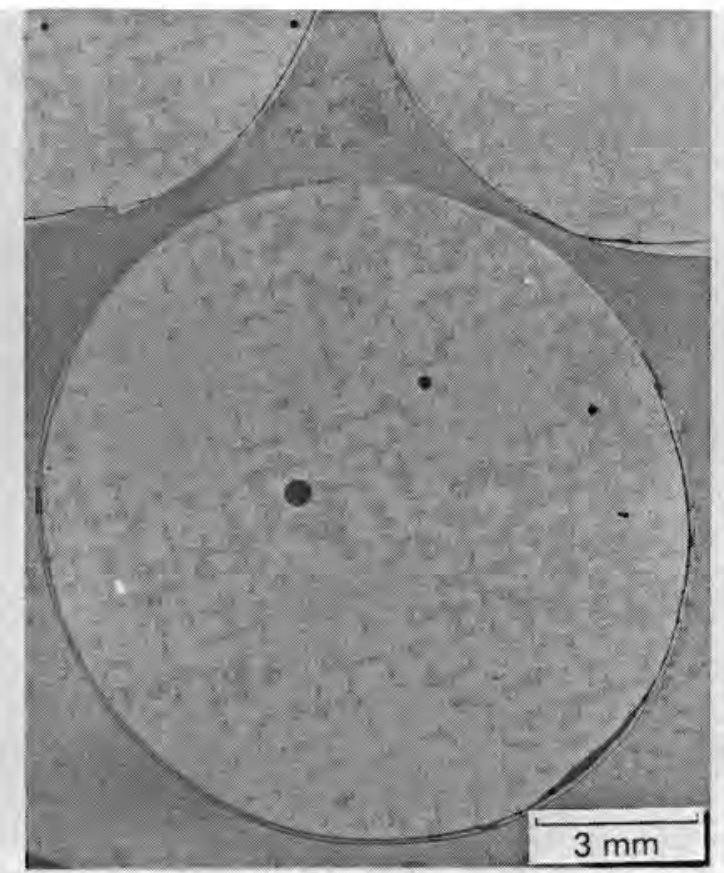

TDS-211

GLASS MARBLE

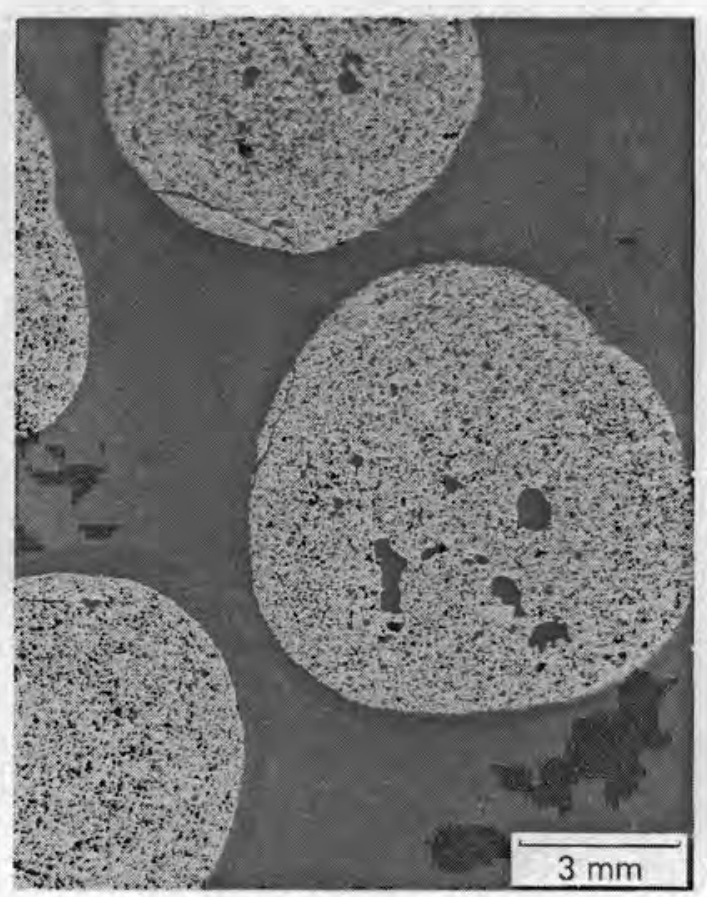

DISC PELLETIZED MB-2

FIGURE 20. Micrographs of Simulated Waste Glass Marbles and Disc Pelletized Ceramics 
TABLE 11. Phase Characterization Data Glass Marble and Ceramic Pellet Waste Forms

\begin{tabular}{|c|c|c|}
\hline Waste Material & Crystalline Phases & $\begin{array}{l}\text { Volume } \\
\text { Fraction }\end{array}$ \\
\hline \multirow[t]{6}{*}{ SPC-4E Supercalcine Pellet } & $\mathrm{Ca}\left(\mathrm{RE}_{8}\left(\mathrm{SiO}_{4}\right)_{6} \mathrm{O}_{2}\right.$ & $\sim 35 \%$ \\
\hline & $(\mathrm{Ce}, \mathrm{Zr} \ldots)_{2}$ & $\sim 20 \%$ \\
\hline & $(\mathrm{Sr}, \mathrm{Ba}, \mathrm{Ca}) \mathrm{MoO}_{4}$ & $\sim 15 \%$ \\
\hline & $(\mathrm{RE}) \mathrm{PO}_{4}$ & $\sim 10 \%$ \\
\hline & $(\mathrm{Cs}, \mathrm{Na}) \mathrm{AlSi}_{2} \mathrm{O}_{6}$ & $\sim 5 \%$ \\
\hline & (uncrystal1ized) & $\sim 15 \%$ \\
\hline \multirow[t]{7}{*}{ SPC-5B Supercalcine Pellet } & $(\mathrm{Ca}, \mathrm{Sr}, \mathrm{Ba})_{2}\left(\mathrm{NaAlSiO}_{4}\right)_{6}\left(\mathrm{MoO}_{4}\right)_{2}$ & $\sim 30 \%$ \\
\hline & $(\mathrm{Na}, \mathrm{K}) \mathrm{AlSiO}_{4}$ & $\sim 20 \%$ \\
\hline & $(\mathrm{Cs}, \mathrm{Na}) \mathrm{AlSi}_{2} \mathrm{O}_{6}$ & $\sim 10 \%$ \\
\hline & $\mathrm{Ca}_{2}(\mathrm{RE})_{8}\left(\mathrm{SiO}_{4}\right)_{6} \mathrm{O}_{2}$ & $\sim 10 \%$ \\
\hline & $(\mathrm{Ce}, \mathrm{Zr}, \ldots.) \mathrm{O}_{2}$ & $\sim 5 \%$ \\
\hline & $\mathrm{RuO}_{2} ; \mathrm{Pd} ;(\mathrm{Ni}, \mathrm{Fe})(\mathrm{Fe}, \mathrm{Cr})_{2} \mathrm{O}_{4}$ & $\sim 5 \%$ \\
\hline & (Uncrystal1ized) & $\sim 20 \%$ \\
\hline \multirow[t]{3}{*}{ MB-2 Ceramic Pellet } & $(\mathrm{Ni}, \mathrm{Mn}) \mathrm{Fe}_{2} \mathrm{O}_{4}$ & $\sim 60 \%$ \\
\hline & $\mathrm{Pb}_{3} \mathrm{Si}_{2} \mathrm{O}_{7}$ & $\sim 30 \%$ \\
\hline & $\mathrm{NaAiSiO}_{4}$ & $\sim 10 \%$ \\
\hline TDS-211 Glass Marble & (Vitreous) & $96-100 \%$ \\
\hline 76-68 Glass Marble & (Vitreous) & $96-100 \%$ \\
\hline
\end{tabular}

Impact tests were conducted on supercalcine SPC-2 pellets and simulated waste glass marbles in a previous study (Rusin 1979). Due to agglomeration of the supercalcine particles, surface area created by the impact force was used as an indication of impact resistance. Surface area after a $217 \mathrm{~J}$ impact was $5700 \mathrm{~cm}^{2} / \mathrm{g}$ for supercalcine SPC-2 pellets $\left(\sim 11 \mathrm{~mm} \mathrm{dia)}\right.$ and $1100 \mathrm{~cm}^{2} / \mathrm{g}$ for simulated waste glass marbles $(\sim 10 \mathrm{~mm}$ dia). Surface area before impact was $1400 \mathrm{~cm}^{2} / \mathrm{g}$ for the SPC-2 pellet and essentially zero for the glass marble. 
Crush strength has been determined by compressing the specimens between hardened steel-bearing blocks of an Instron ${ }^{\circledR}$ testing machine. The crush strength of TDS- $211 \mathrm{glass}$ marbles $(\sim 13 \mathrm{~mm} \mathrm{dia})$ was found to be $880 \pm 50 \mathrm{~kg}$. The crush strength of MB-1 and MB-2 pellets ( 8 to $12 \mathrm{~mm} \mathrm{dia)} \mathrm{was} 520 \mathrm{~kg}$ and $320 \mathrm{~kg}$, respectively. Crush strength of $1.5 \mathrm{~mm}$ dia supercalcine SPC-2 particles was found to be $\sim 5 \mathrm{~kg}$.

\section{LEACH RESISTANCE}

Leach resistance for selected consolidated waste forms is summarized in Table 12. The results are normalized in standard units of $\mathrm{g} / \mathrm{m}^{2} \cdot \mathrm{d}$ to allow for ease in comparing sample types. Normalization procedures are presented elsewhere (Nelson 1981).

TABLE 12. Leaching Results for Consolidated Waste Forms(a)

\begin{tabular}{|c|c|c|c|c|c|c|c|c|c|c|}
\hline \multirow[b]{2}{*}{ Waste Form } & \multicolumn{10}{|c|}{ Normalized Release, $\mathrm{g} / \mathrm{m} \cdot \mathrm{d}$} \\
\hline & Si & $\bar{B}$ & $\mathrm{Na}$ & $\mathrm{Ba}$ & $\mathrm{Ca}$ & Mo & $\mathrm{sr}$ & CS. & Nd & $\mathrm{Ce}$ \\
\hline $76-68$ Glass Marble(b) & 0.66 & 1.05 & 0.89 & 0.01 & 0.06 & 1.04 & 0.06 & 1.08 & $-(c)$ & -- \\
\hline TDS-211 Glass Marble & 0.44 & 0.50 & 0.50 & -- & -- & -- & 0.10 & 0.70 & $<0.01(\mathrm{~b})$ & $<0.03$ \\
\hline SPC-2 Ceramic Pellet & 6.0 & -- & -- & 2.4 & 2.2 & 17 & 20 & 3.1 & -- & -- \\
\hline SPC-4 Ceramic Pellet & 6.0 & -- & -- & 6.9 & 1.7 & 8.9 & 6.0 & 4.8 & -- & -- \\
\hline SPC-4E Ceramic Pellet(b) & 0.9 & -- & 2.1 & 0.5 & 0.5 & 1.3 & 0.5 & 0.3 & -- & -- \\
\hline MB-2 Ceramic Pellet(b) & $\ldots$ & - & 4.2 & -- & $\ldots$ & -- & 2.4 & 36 & $<0.001$ & $<0.003$ \\
\hline
\end{tabular}

(a) Deionized water, $90^{\circ} \mathrm{C}, \mathrm{SA} / \mathrm{V}=10 \mathrm{~m}^{-1}, 28$ days unless indicated otherwise

(b) 14-day data

(c) Not present or not analyzed for

(d) < indicates detection limit

${ }^{\circledR}$ Instron Corporation, Canton, Massachusetts. 


\section{ADVANTAGES AND DISADVANTAGES OF GLASS MARBLES AND CERAMIC PELLETS}

Marbles and ceramic pellets have characteristics that make them more attractive, or less attractive than glass monoliths depending on the properties that may be required for HLW immobilization and disposal. Some of these characteristics are related to $Q A$ requirements, recycling, bulk disposal, fracture resistance, process complexity, waste loading, surface area, thermal stability, and incorporation of crystalline phases. In this section, these characteristics are contrasted with those of glass monoliths.

\section{ADVANTAGES OF GLASS MARBLES}

- Little, if any, devitrification and phase separation is evident

The presence of devitrification crystals dispersed in monolithic glass may cause microcracking, which may increase the surface area and the leachability of the glass. The presence of crystals in the glass, coupled with uneven phase density changes caused by radiation, may also lead to increased cracking of the glass and subsequent increased leaching. The extent of devitrification varies significantly within a glass monolith as a function of the cooldown history of the glass. The glass near the canister walls is not extensively devitrified as is the glass at the center of the canister. Hence, the possible long-term effects are difficult to quantify.

Soluble crystals have been encountered growing on exposed surfaces of some monolithic glasses produced at PNL, which contain either simulated commercial and SRP wastes. These crystals are largely composed of alkali silicates and molybdates, which suggests that the retention of cesium in these large monoliths may not be as high as desired. The presence of these crystals may be attributed to the separation of watersoluble phases from the glass during the slow cooling of the glass. These water-soluble phases are easily dissolved by leachates and are carried to exposed surfaces where they collect as crystals. In contrast, phase separation has not been observed on glass marbles, possibly because 
the kinetics for this phenomenon may be too slow to occur during marble production.

- Marbles are amenable to QA requirements

Glass marbles are of a size and shape that permit easy sampling and analysis. In comparison, representatively sampling a monolith is difficult since the properties of the glass vary as a function of its cooldown history and because the waste composition and the glass formersto-waste ratio varies. One can obtain grab samples of the glass as it is poured, but it is difficult to do so while attempting to simulate the thermal history of the glass in the canister. Moreover, remote sampling of the pouring glass stream is much more difficult than the sampling of marbles. Core drilling is an undesirable method of sampling glass monoliths since it breaches the canister and may be difficult to perform without spreading contamination.

- Marbles are amenable to recycling

Marbles can be very simply recycled in a glass-melting furnace. A method to recycle off-standard glass monoliths has not been developed due to the obvious difficulties of recycling such waste forms.

- Marbles are amenable to bulk disposal

If marbles, or coated marbles, can simply be poured into engineered cavities in a specially built repository located at the site of the marble-making plant, significant cost savings may result. Personnel exposure should also be substantially reduced. This approach could not occur at a facility distant from a repository such as SRP, but could occur at the Hanford Project, Nevada Test Site, or Waste Isolation Pilot Plant.

- Marbles are very fracture resistant

Marbles, especially marbles coated with porous metal, are extremely resistant to breakage and fines generation. Because of this property, marbles may offer a means of significantly lowering the risk of disposing of HLW. 
- Marbles in a metal matrix improve the thermal conductivity of the waste form

For defense wastes, apparently thermal conductivity is not a problem because wastes are sufficiently "old" and dilute that their thermal heat contents are low. For "young" commercial wastes, however, improved thermal conductivity could be a significant advantage. This is because the centerline temperature of commercial monolithic glass may be close to the temperature at which the glass is "molten", depending on the diameter of the canister and its storage conditions. The predictability of very hot glass is uncertain because phenomena such as crystal growth, density changes, volatility, migration, etc., are greater at higher temperatures. For commercial HLW glass monoliths, fins are used in the canister to maintain the glass at a reasonably low temperature. Still centerline temperatures may exceed wall temperatures by several hundred degrees centigrade.

In contrast, the improved thermal conductivity created by a metal matrix around marbles essentially evens out the temperature of the glass due to reduced temperature gradients. Acceleration of leaching due to increased temperature would be reduced. This may not be the case with cracked monoliths, which in a sealed repository may be exposed to leaching solutions at $80^{\circ} \mathrm{C}$ at the surface of the monolith and above $150^{\circ} \mathrm{C}$ inside the monolith. Such high-temperature leaching conditions will persist until the cracks in the glass become corroded away enough to improve thermal transfer. Glasses at $150^{\circ} \mathrm{C}$ and higher have a much lower resistance to leaching solutions than glasses at $90^{\circ} \mathrm{C}$ and lower (Westsik 1980).

- Marble making is a relatively simple extension of the well-established waste glass technology

Various studies (Johnson 1980; Treat and Nesbitt 1980) have rated the marble process somewhat more complex than the monolithic glass processes but considerably less complex than all but the cast concrete process. 
As such, the marble process serves as a backup if the potential monolithic glass problems of devitrification, phase separation, high internal temperatures, $Q A$ and recycling, cannot be acceptably resolved.

\section{DISADVANTAGES OF MARBLES}

- The process is more complex than the monolithic-glass process

Although marble making is more complex than the monolithic glass processes, marble making is still one of the simplest waste immobilization alternatives (as previously stated).

- Lower volumetric waste loadings are experienced with marbles

Low volumetric waste loadings are a concern with low heat-generating waste, such as SRP and Hanford wastes, because $70 \%$ more canisters will be required. This in not a concern with commercial waste for which the volume of canister contents will likely be limited by heat load. The repository limits on canister dimensions are sufficiently wide that the same number of commercial waste canisters will be generated, whether containing marbles or monolithic glass. Hence, repository and transportation costs will be similar. The cost of the larger canister and the metal matrix-forming material is relatively insignificant.

- On a waste-equivalent basis, marbles have a much higher surface area than monolithic glass

One-centimeter-diameter marbles have a relative surface area 83 times that of uncracked monoliths (measuring $2 \mathrm{ft}$ dia. $\times 9 \mathrm{ft}$ ). However, glass monoliths produced at PNL without annealing are cracked to the extent that the real surface area is about 20 times that of uncracked glass. Hence, marbles have about 4 times greater surface area. As previously stated, very high leaching rates that may be experienced in glass monoliths under high-temperature conditions may completely overshadow the surface area differences. The possibility of refluxing (stream formation and condensation) within the cracked glass monolith if 
the pressure around the canister is near atmospheric pressure may also result in very high dissolution rates, which again may overshadow the surface area difference.

\section{ADVANTAGES OF CERAMIC PELLETS}

- High waste loadings can be achieved

To make ceramic pellets, the necessary additives weigh only about one-half that of the waste. To make glass, the necessary additives weigh two to four times that of the waste. Moreover, the density of ceramic pellets is about $40 \%$ greater than that of glass. These characteristics enable ceramic pellets to occupy only about one-third the volume occupied by glass marbles and about $55 \%$ of the volume of monolithic glass. Only for low heat-generating wastes is this an important advantage since it reduces canister requirements by a proportionate amount. This advantage does not apply to high heat-generating wastes for which canister waste loadings are heat-1imited.

- Crystalline materials are more thermodynamically stable than glass

Crystalline ceramics, if properly made, strongly resist chemical and physical changes even at temperatures and pressures likely to exist in repositories. Glasses, on the other hand, may be subject to partial crystallization given sufficient time at elevated temperatures and pressures. The result of such crystallization may be increased cracking and/or a general reduction in the leach resistance of the waste form. Ceramic pellets, having a higher melting temperature than that of glass, may also be expected to better withstand accidents involving fire.

- Ceramic pellets are amenable to QA requirements and bulk disposal and may be encapsulated in a metal matrix to provide further protection

The same advantages presented for glass marbles apply to ceramic pellets. 


\section{DISADVANTAGES OF CERAMIC PELLETS}

- Approximately 30 waste elements present in HLW are difficult to simultaneously incorporate into stable crystalline phases

Several waste elements resist being combined with other elements in attempts to make desirable crystalline phases. Examples are palladium and ruthenium oxide which simply exist in supercalcine formulations as unreacted particles. The alkalis, such as sodium and cesium, also resist crystallization and may finally reside partly in silica-rich glassy phases. Molybdenum resists incorporation into leach-resistant phases and may finally reside partly in water-soluble salts.

- The process for making ceramic pellets is more complex than those for making glass monoliths and marbles

Recent studies (Johnson 1980; Treat and Nesbitt 1980) have judged a process for making ceramic pellets to be more complex than any of the glass processes. The ceramic pellet process involves more processing steps, many of which require the undesirable mechanical handling of powders and pellets. The required sintering kiln(s) may be difficult to operate because of the tendency for pellets to sinter together.

- The high waste loadings, and the need to add rather exact amounts of additives to make supercalcine, require a precise knowledge of waste composition

More samples and more accurate analyses of samples are required to avoid producing off-standard ceramic pellets.

- Recycling ceramic pellets is more difficult than recycling glass marbles

Recycling ceramic pellets probably requires milling to a fine powder and blending the powder with suitable additives. These mechanical steps may be difficult to accomplish remotely, especially without spreading contamination.

- Ceramic pellets have rougher surfaces than glass marbles

Ceramic pellets may be more prone to chipping and abrasion, which may result in contamination problems during final product processing. 
Two waste form cores, glass marbles and ceramic pellets, were developed as part of the multibarrier concept for immobilizing nuclear wastes. These waste form cores have shapes and sizes that facilitate quality assurance and recycling. These waste forms may also be encapsulated in metal, such as lead, to improve their thermal conductivities and provide additional containment. Conclusions developed from studies done at PNL on glass marbles and ceramic pellets, and recommendations, follow.

- Marbles

Hundreds of kilograms of simulated waste-glass marbles have been produced in equipment that could be adapted for remote operation. The process for making marbles serves a good backup to processes that yield monolithic glass since marble-making utilizes existing glass process technology. Moreover, the marble process has been judged as one of the more feasible alternatives for immobilizing nuclear wastes. The attractiveness of this process may be enhanced if a large turntable concept for making marbles can be demonstrated.

Before any marble process can be judged ready for application to high-level wastes, its operation and maintenance should be proven under fully remote conditions. If the potential monolithic glass problems of devitrification, phase separation, high internal temperatures, $Q A$, and recycling cannot be acceptably resolved, we recommend the continued development of marble-making technology.

- Pellets

Various pellet formulations have been generated including "supercalcine," a silicate-based ceramic for immobilizing commercial high-level nuclear wastes, and a sintered-ceramic for immobilizing highlevel wastes currently stored at Savannah River Plant.

The process for making pellets requires that the liquid waste first be dried to a powder in a device such as a spray calciner. The powders 
may then be agglomerated into $\sim 1 \mathrm{~cm}$ dia spherical pellets in a disc pelletizer. A pin mixer may be used to produce $\sim 1 \mathrm{~mm}$ particles. After drying, the spherical pellets or particles must be sintered at temperatures between $1000^{\circ} \mathrm{C}$ and $1200^{\circ} \mathrm{C}$ to cause the desired densification and crystal growth.

Relative to the marble process, the pellet process is very complicated. In addition to the higher number of processing steps, several material transfer steps are required that involve handling dusty solids. Controlling the process is more of an "art" than a science and will require frequent visual observation. Sintering will require a very large furnace volume(s) and may produce significant losses of volatile waste species, such as cesium and ruthenium. The product pellets also tend to be porous, somewhat dusty, and may be discharged from the sintering furnaces as an agglomerated mass unless careful compositional control is maintained. For these reasons, the further development of ceramic pellets is not desirable. Instead, we suggest that any additional efforts to develop ceramic waste forms, if any, be directed toward the production of large billets. 


\section{REFERENCES}

Barnes, S. M. 1980. High-Temperature Vitrification of Hanford Residual-Liquid Waste In a Continuous Melter. PNL-3343, Pacific Northwest Laboratory, Richland, WA 99352.

Barnes, S. M. and D. E. Larson. 1981. Materials and Design Experience in a Slurry-Fed Electric Glass Melter. PNL 3959, Pacific Northwest Laboratory, Richland, WA 99352

Brouns, R. A., G. B. Mellinger, T. A. Nelson, and K. H. Oma. 1980. Immobilization of High-Level Defense Waste in a Slurry-Fed Electric Glass

Melter. PNL-3372, Pacific Northwest Laboratory, Richland, WA 99352.

Bunnel, L. R. 1979. Tests for Determining Impact Resistance and Strength of Glass for Nuclear Waste Disposal. PNL-2925, Pacific Northwest Laboratory, Richland, WA 99352.

Chapman, C. C. 1976. Experience with a Joule-Heated Ceramic Melter While Converting Simulated High-Level Waste to Glass. BNWL-2071, Pacific Northwest Laboratory, Richland, WA 99352.

Dierks, R. D. 1980. The Design and Performance of a 100-kg/h, Direct CalcineFed Electric - Melter System for Nuclear-Waste Vitrification. PNL-3387, Pacific Northwest Laboratory, Richland, WA 99352.

Ferguson, R. B., G. B. Woolsey, R. M. Galloway, P. K. Baumgarten, and R. E. Eibling. 1980. "A Small-Scale Integrated Demonstration of High-Level Radioactive Waste Processing and Vitrification Using Actual SRP Wastes." In Proceedings of the International Symposium on the Scientific Bas is for Nuclear Waste Management, II I, Boston, Massachusetts. J. G. Moore, Ed.

Goldman, M. I., J. A. Servizi, R. S. Daniels, T. H. Y. Tebbutt, R. T. Burns, and R. A. Lauderdal. 1958. "Retention of Fission Products in Ceramic-GlazeType Fusions", Proceedings of 2nd UN International Conference Peaceful Uses Atomic Energy, 1958, Geneva, 18, 27, United Nations, NY.

Hanson, M. S. and W. J. Bjorklund. 1980. Vitrification of Radioactive HighLevel Waste by Spray Calcination and In-Can Melting. PNL-3145, Pacific Northwest Laboratory, Richland, WA 99352.

Johnson, E. R., Associates, Inc. 1980. Preliminary Evaluation of Alternative Waste Form Solidification Processes, Volume II: Evaluation of the Processes. PNL-3477, Pacific Northwest Laboratory, Richland, WA 99352.

Larson, D. E. 1980. Spray Calciner/In-Can Melter High-Level Waste Solidification Technical Manual. PNL-3495, Pacific Northwest Laboratory, Richland, WA 99352. 
Ledford, J. A., and P. M. Williams. 1979. "Utilization of Borosilicate Glass For Transuranic Waste Immobilization" Proceedings of Ceramics in Nuclear Waste Management, CONF-790420, Cincinnati, Ohio.

Lukacs, J. M., J. M. Rusin, and R. L. Treat. 1979. "Disc Pelletization of Simulated Crystalline Nuclear Waste." In Proceedings of the Sixteenth Biennial Conference of the Institute for Briquetting and Agglomeration, Volume 16, San Diego, CA.

McCarthy, G. J. 1977. "Ceramics and Glass-Ceramics as High-Level Waste Forms." In Proceedings of the Conference on Ceramic and Glass Radioactive Waste Forms, CONF-770102.

McElroy, J. L., compiler, 1975. Quarterly Progress Report, Research and Development Activities, Waste Fixation Program, April-June 1975. BNWL-1932, Pacific Northwest Laboratory, Richland, WA 99352.

McElroy, J. L., K. J. Schneider, J. N. Hartley, J. E. Mendel, G. L. Richardson, R. W. McKee, and A. G. Blasewitz. 1972. Waste Solidification Program Summary Report, Vol. II, Evaluation of WSEP High Level Waste Solidification Processes. BNWL-1667, Pacific Northwest Laboratory, Richland, WA 99352.

Morgan, P. E. D., et a1. 1981. "High Alumina Tailored Nuclear Waste Ceramics." J. Am. Ceram. Soc. 64(5).

Nelson, R. G., J. F. Nesbitt, and S. C. Slate. 1981. Nuclear Waste Encapsulation by Metal Matrix Casting. PNL-3750, Pacific Northwest Laboratory, Richland, WA 99352.

Nelson, R. D., ed. 1981. Materials Characterization Center Test Methods: Preliminary Version. PNL-3990, Pacific Northwest Laboratory, Richland, WA 99352.

Nesbitt, J. F. and C. M. Ryer. 1980. Developing and Testing a Vertical Sintering Furnace for Remote Nuclear Applications. PNL-3245, Pacific Northwest Laboratory, Richland, WA 99352.

Nesbitt, J. F. and R. L. Treat. 1980. "Alternative Waste Forms: Process Feasibility." In Proceedings of the 82nd Annual Meeting and Exposition of the American Ceramic Society, Chicago, Illinois.

Oma, K. H. et al. 1981. Coated Particle Waste Form Development. PNL-4108, Pacific Northwest Laboratory, Richland, WA 99352.

Ringwood, A. E., S. E. Kesson, N. G. Ware, W. O. Hibberson and A. Major. 1979. The SYNROC Process: A Geochemical Approach to Nuclear Waste Immobilization. Research School of Earth Sciences, Australian National University, Canberra, A.C.T. 2600, Australia. 
Ross, W. A. et al. 1978. Annual Report on the Characterization of High-Level Waste Glasses. PNL-2625, Pacific Northwest Laboratory, Richland, WA 99352 .

Rusin, J. M. et a1. 1978. Multibarrier Wastes Forms Part I: Development. PNL-2668-1, Pacific Northwest Laboratory, Richland, Washington.

Rusin, J. M. et a1. 1979. Multibarrier Waste Forms Part II: Characterization and Evaluation PNL-2668-2, Pacific Northwest Laboratory, Richland, WA 99352.

Rusin, J. M. 1981. An Assessment of Glass-Ceramic Waste Forms. PNL-3515, Pacific Northwest Laboratory, Richland, WA 99352.

Rusin, J. M., M. F. Browning and G. J. McCarthy. 1979. "Development of Multibarrier Nuclear Waste Forms." In Scientific Basis for Nuclear Waste Management, VI, G. J. McCarthy, ed., Plenum Press, New York, NY.

Shund, E. B. 1958. Glass Engineering Handbook. Second Edition, McGraw Hill Book Company, New York, NY.

Sombret, C., R. Bonniaud, and A. Jouan. 1978. "Large-Scale Waste Glass Production." In Proceedings of the Conference on High-Level Radioactive Solid Waste Forms, NUREG/CP-0005, Denver, CO, L. A. Casey, Ed.

Van Geel, J. H. Eschrich, F. Dabbels, P. Favre, and H. Sterner. 1980. Embedding of Solid High-Level Wastes into Metal and Non-Metal Matrices, European Company for the Chemical Processing of Irradiated Fuels Report ETR296.

Wald, J. W. et. al. 1981. Development and Testing of Matrices for the Encapsulation of Glass and Ceramic Nuclear Waste Forms. PNL-4098, Pacific Northwest Laboratory, Richland, WA 99352.

Watson, L. C., R. C. Durham, W. E. Erlebach, and H. K. Rae. 1958. "The Disposal of Fission Products in Glass," Proceedings of 2nd UN International Conference Peaceful Uses Atomic Energy, 1958, Geneva, 18, 27, United Nations, NY.

Westsik, Jr., J. H., J. W. Shade, and G. L. McVay. 1980. "Temperature Dependence of Hydrothermal Reactions with Waste Glasses and Ceramics," in Scientific Basis for Nuclear Waste Management, Vol. 2, Plenum Press, New York, New York.

White, J. M., and G. LaHaie. 1955. Ultimate Fission Product Disposal, the Disposal of Curie Quantities of Fission Products in Siliceous Materials. CRCE-591, Atomic Energy of Canada Ltd. 


\section{ACKNOWLEDGMENTS}

The information in this report was compiled from studies performed by fellow researchers at Pacific Northwest Laboratory. We wish to acknowledge their contributions. Individual contributors and their areas of expertise are:

- Glass Melters--J. L. Buelt, R. A. Brouns

- Marble Machines--S. C. Slate

- Ceramic Formulations--G. J. McCarthy (Pennsylvania State University), H. T. Blair

- Spray Calcination--W. J. Bjorklund, C. L. Timmerman

- Pellet Agglomeration--C. L. Timmerman, J. G. Carter

- Pellet Sintering--C. L. Timmerman, J. F. Nesbitt

- Characterization--C. Q. Buckwalter, R. 0. Lokken, J. W. Wald, R. P. May. 
No. of

Copies

\section{OFFSITE}

A. A. Churm

DOE Chicago Patent Group

9800 South Cass Avenue

Argonne, IL 60439

R. B. Chitwood

DOE Nuclear Waste Management

Fuel Cycle Programs

NE-30 , GTN

Washington, D. C. 20545

2 R. Y. Lowrey

DOE Albuquerque Operations Office

P. 0. Box 5400

Albuquerque, NM 87185

A. L. Taboas

DOE Albuquerque Operations Office

P. 0. Box 5400

Albuquerque, NM 87185

S. A. Mann

DOE Chicago Operations and Region Office

Argonne, IL 60439

J. 0. Neff

Department of Energy

Columbus Program Office

505 King Avenue

Columbus, $\mathrm{OH} 43201$

W. E. Mott

DOE Division of Environmental Control Technology

Washington, DC 20545

J. P. Hamric

DOE Idaho Operations Office

550 2nd St.

Idaho Falls, ID 83401
No. of

Copies

J. W. Peel

DOE Idaho Operations Office

550 2nd St.

Idaho Falls, ID 83401

J. B. Whitsett

DOE Idaho Operations Office

550 2nd St.

Idaho Falls, ID 83401

C. R. Cooley

DOE Nuclear Waste Management Programs

NE-331, GTN

Washington, DC 20545

0 . Gormley

DOE Nuclear Waste Management

Programs

NE-30, GTN

Washington, DC 20545

C. A. Heath

DOE Nuclear Waste Management Programs

NE-330, GTN

Washington, DC 20545

M. L. Lawrence

DOE Nuclear Waste Management

Fuel Cycle Programs

NE-30, GTN

Washington, DC 20545

J. A. McBride

E. R. Johnson Associates, Inc.

11702 Bowman Green Drive

Reston, VA 22090

S. Meyers/R. Romatowski

DOE Nuclear Waste Management

Programs

NE-30, GTN

Washington, DC 20545 
No. of Copies

R. W. Ramsey, Jr.

DOE Nuclear Waste Management Programs

NE-301, GTN

Washington, DC 20545

V. Trice

DOE Nuclear Waste Management Programs

NE-30, GTN

Washington, DC 20545

D. L. Vieth

DOE Nuclear Waste Management Programs

NE-332, GTN

Washington, DC 20545

E. J. Wahquist

DOE Nuclear Waste Management

Fuel Cycle Programs

NE-30, GTN

Washington, D. C. 20545

2 S. W. Ahrends

DOE Oak Ridge Operations Office

P. 0. Box E

Oak Ridge, TN 37830

Office of the Assistant Manager for Energy and Development

DOE Oak Ridge Operations Office

P. 0. Box E

Oak Ridge, TN 37830

S. G. Harbinson

DOE San Francisco Operations Office

1333 Broadway

Oakland, CA 94612

W. B. Wilson

DOE Savannah River Operations Office

P. 0. Box A

Aiken, SC 29801
No. of

Copies

R. P. Whitfield

DOE Savannah River Operations Office

P. 0. Box A

Aiken SC 29801

J. B. Martin

Division of Waste Management Nuclear Regulatory Commission Washington, DC 20555

R. D. Smith

Division of Waste Management

Nuclear Regulatory Commission

Washington, DC 20555

R. E. Cunningham

Office of Nuclear Safety Materials and Safeguards

Nuclear Regulatory Commission

Room 562, 7915 Eastern Avenue

Silver Spring, MD 20910

27 DOE Technical Information Center

J. A. Buckham

Allied-General Nuclear Services

P. 0. Box 847

Barnwell, SC 29812

A. Williams

Allied-General Nuclear Services

P. 0. Box 847

Barnwell, SC 29812

J. W. Bartlett

The Analytical Sciences Corp.

6 Jacob Way

Reading, MA 01867

J. H. Kittel

Argonne National Laboratory

Office of Waste Management

Programs

9700 South Cass Avenue

Argonne, IL 60439 
No. of

Copies

M. J. Steindler/L. E. Trevorrow Argonne National Laboratory 9700 South Cass Avenue Argonne, IL 60439

W. Carbiener

Battelle Memorial Institute

Office of Nuclear Waste Isolation

505 King Avenue

Columbus, $\mathrm{OH} 43201$

Beverly Rawles

Battelle Memorial Institute

Office of Nuclear Waste Isolation

505 King Avenue

Columbus, $\mathrm{OH} 43201$

Research Library

Battelle Memorial Institute

505 King Avenue

Columbus, $\mathrm{OH} 43201$

M. D. Boersma

E. I. duPont de Nemours and Co. Savannah River Laboratory

Aiken, SC 29801

J. L. Crandall

E. I. duPont De Nemours and Co. Savannah River Laboratory

Aiken, SC 29801

D. E. Gordon

E. I. duPont de Nemours and Co. Savannah River Laboratory

Aiken, SC 29801

T. H. Gould, Jr.

E. I. duPont de Nemours and Co. Savannah River Laboratory

Aiken, SC 29801
No. of

Copies

J. A. Stone

E. I. duPont de Nemours and Co. Savannah River Laboratory

Aiken, SC 29801

A. L. Ayers

E.G. and G. Idaho

P. 0. Box 1625

Idaho Falls, ID 83415

R. Williams

Electric Power Research Institute

3412 Hillview Avenue

Palo Alto, CA 94304

Environmental Protection Agency

Technological Assessment

Division (AW-559)

Office of Radiation Programs

Washington, DC 20460

J. R. Berreth

Exxon Nuclear Idaho

P. 0. Box 2800

Idaho Falls, ID 83401

File Copy

Exxon Nuclear Idaho

P. 0. Box 2800

Idaho Falls, ID 83401

J. Campbel 1

Lawrence Livermore Laboratory

P. 0. Box 808

Livermore, CA 94550

R. Roy

202 Materials Research Laboratory

Pennsylvania State University

University Park, PA 16802

J. P. Duckworth

Plant Manager

Nuclear Fuels Services, Inc.

P. 0. Box 124

West Valley, NY 14171 
No. of

Copies

R. E. Blanco

Oak Ridge National Laboratory P. 0. Box $Y$

Oak Ridge, TN 37830

W. J. Lackey

Oak Ridge National Laboratory

Oak Ridge, TN 37830

T. H. Row

Oak Ridge National Laboratory

P. 0. Box X

Oak Ridge, TN 37830

H. Recht

Dept. 737-710

Atomics International Division

Rockwell International

Box 309

Canoga Park, CA 91304

W. S. Bennett

Rockwell International

Rocky Flats Plant

P. 0. Box 464

Golden, C0 80401

R. G. Post

College of Engineering

University of Arizona

Tucson, AZ 85721

L. L. Hench

Dept. of Materials Science and Engineering

University of Florida

Gainesville, FL 32611

ONSITE

4 DOE Richland Operations Office

J. J. Schreiber (2)

R. E. Gerton

H. E. Ransom
No. of

Copies

2 Rockwell Hanford Operations

I. E. Reep

D. D. Wodrich

Westinghouse Hanford Company

A. G. Blasewitz

67 Pacific Northwest Laboratory

W. J. Bjorklund

H. T. Blair

W. F. Bonner

D. J. Bradley

D. W. Brite

C. Q. Buckwalter

R. L. Bunnell

J. R. Carrell

T. D. Chikalla

H. T. Fullam

W. J. Gray

W. E. Gurwell

C. R. Hann

M. S. Hanson

L. K. Holton

J. H. Jarrett

R. S. Kemper

S. E. King

D. E. Knowlton

C. A. Knox

L. T. Lakey

D. E. Larson

R. 0. Lokken

G. L. McVay

J. E. Mendel

R. G. Nelson

J. F. Nesbitt

R. E. Nightingale

K. H. Oma

A. M. Platt

W. A. Ross

J. M. Rusin (10)

D. H. Siemens

S. C. Slate

C. L. Timmerman

R. L. Treat (10) 
No. of

Copies

Pacific Northwest Laboratory

(contd)

R. P. Turcotte (2)

H. H. VanTuyl

J. W. Wald

R. E. Westerman

Technical Information (5)

Publishing Coordination (2) 